
of a Middle Devonian Coal in Illinois

\author{
R. A. Peppers \\ H. H. Damberger
}

CIRCULAR 445

ILLINOIS STATE GEOLOGICAL SURVEY URBANA, ILLINOIS 61801 John C. Frye, Chief 

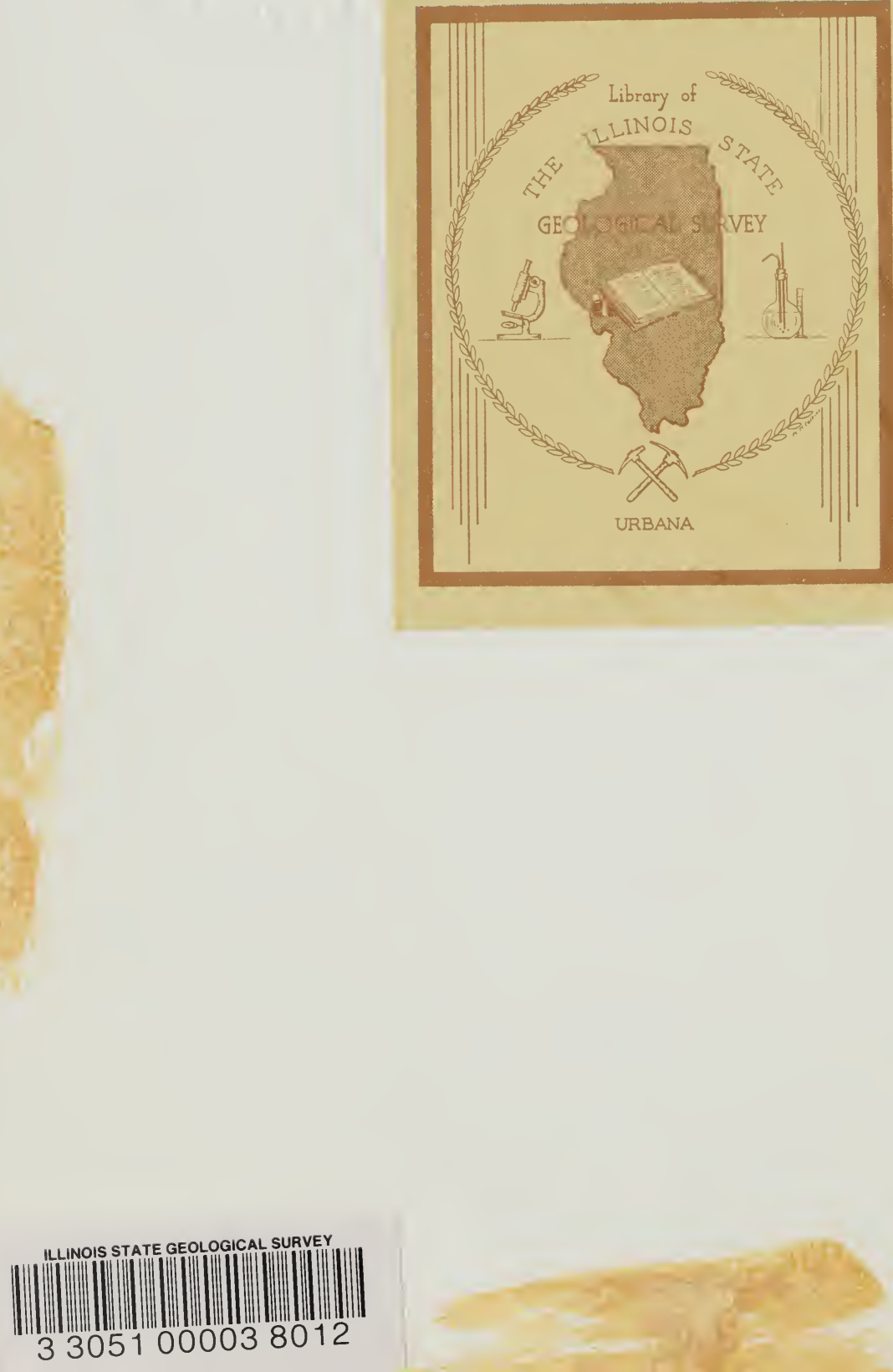


\title{
PALYNOLOGY AND PETROGRAPHY OF A MIDDLE DEVONIAN COAL IN ILLINOIS
}

\author{
R. A. Peppers and H. H. Damberger
}

\section{ABSTRAC T}

Samples of a carbonaceous sediment, varying from coal to coaly shale and less than 1 to 2 inches thick, were obtained from three diamond drill cores of the Wapsipinicon Limestone in McLean and northern DeWitt Counties, Illinois. This is the only known occurrence of Devonian coal in Illinois.

Microscopic examination of polished samples in reflected light reveals that the coal is only partly laminated. The nonlaminated, less coaly portion may represent reworked material. Spores account for about 12 percent of the laminated coal and only 3 percent of the nonlaminated portion. The rest of the coal consists of the maceral vitrinite. Mineral matter includes pyrite, limestone, quartz, dolomite, calcite, and very fine-grained argillaceous carbonates.

The macerated coal constituents consist of small, irregularly shaped plant fragments, unornamented circular bodies that are perhaps algal in origin, and plant spores. Of the 28 species and 13 genera of small spores that were identified, 6 species are named and described as new. The most frequently encou ntered spore genera, in decreasing a bundance, are Apiculatasporites, Retusotriletes, Spinozonotriletes, Acanthotriletes, Lycospora, Emphanisporites, and Rhabdosporites. Plant microfossils of marine ori gin-Tasmanites, Leiosphaeridia, and Veryhachium-were also observed in the macerations. The spore assemblage does not resemble any previously described Devonian as semblage.

The coal was deposited along the northern flank of the Sangamon Arch, which was essentially standing above sea level during most of the Devonian Period. Most of the 
organic constituents were probably derived from small hydrophilous land plants. The marine plant microfossils that were incorporated in the coal probably came from near the environment of deposition, which was favorable for the growth of marine organisms. Fine lamination of the coal indicates that the plant material, clay, and lime mud were deposited in calm water, but some reworking took place. A reducing environment of deposition is suggested by the presence of a large proportion of syngenetic fine-grained pyrite aggregates and the absence of fusinite and other inertinite macerals. The presence of rounded and well sorted quartz grains throughout the coal and especially in the adjacent limestone (up to 50 percent) suggests a nearshore environment.

\section{INTRODUCTION}

Samples of a thin coal and coaly shale of Middle Devonian age (early Givetian of Europe) were recovered from three diamond drill cores from central Illinois. This is the first published report of a Devonian coal found in Illinois and is the second (Sanders, 1967) published report in the United States that describes in detail the palynology of a Devonian coal. The samples were also submitted for petrographic and chemical analyses.

The investigation was undertaken first to describe the spores so that a comparison might be made between the Illinois assemblage and Middle Devonian assemblages from other parts of the world. An added incentive for describing the Illinois assemblage is that the age of the Illinois stratum is well substantiated by other paleontologic and stratigraphic data, whereas this has not been true for some of the other described Devonian spore floras. In addition, it was hoped that a paleoecological interpretation could be made, based on available data.

\section{Acknowledgments}

We are grateful to Dr. D. C. McGregor, Geological Survey of Canada, who made useful suggestions concerning the descriptive palynology. We also wish to acknowledge two members of the Illinois State Geological Survey, Dr. Donald Dickerson, of the Chemical Group, for the chemical analysis of the coal, and Dr. Harold Gluskoter, of the Coal Section, for the analysis of the mineral-matter residue obtained from the sample by low-temperature ashing.

\section{STRATIGRAPHY AND PETROGRAPHY}

The carbonaceous stratum was found in two cores drilled in McLean County and one drilled in DeWitt County (text figs. 1 and 2, and table 1). The coal and coaly shale were deposited as part of the Davenport Limestone Member, the uppermost member of the Middle Devonian Wapsipinicon Limestone. In 1895, Norton named the Wapsipinicon Limestone for the strata between the Cedar Valley Limestone and the Silurian System along the Wapsipinicon River in east-central Iowa. The names Lower and Upper Davenport were proposed also by Norton (1894) for 


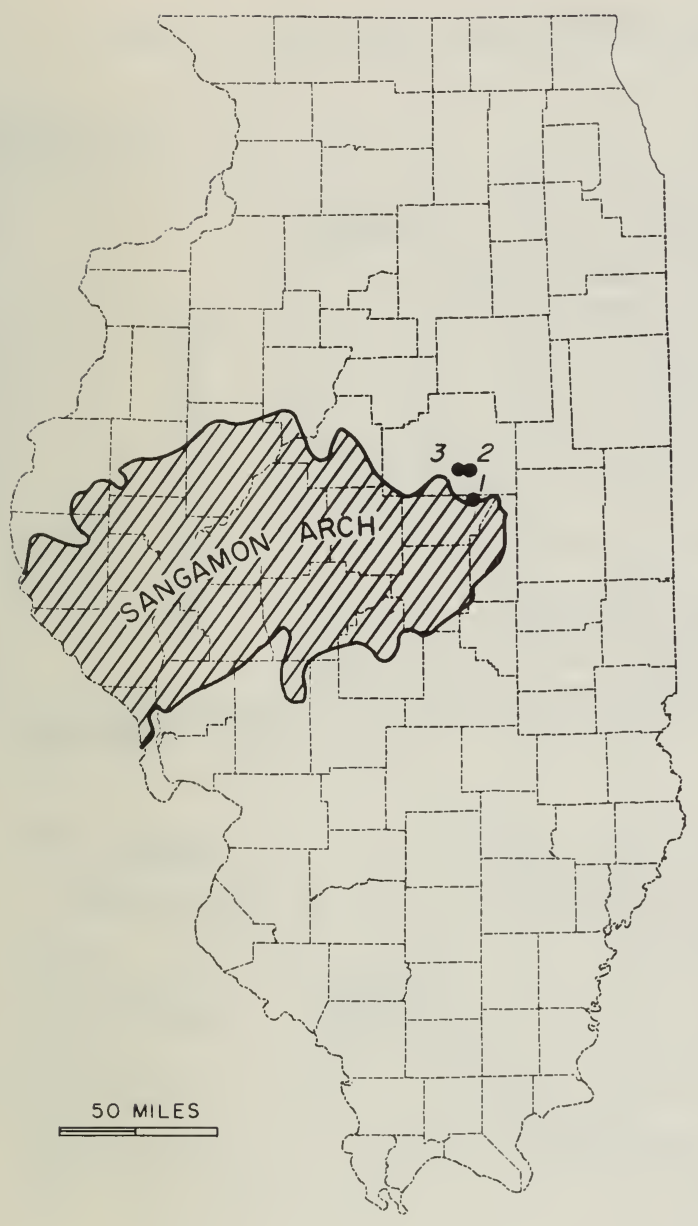

Text fig. 1 - Locations of samples 1, 2, and 3 and their positions relative to the Sangamon Arch during the deposition of the Devonian coal in Illinois. a dense, light to dark gray limestone near Davenport, Iowa. The Upper Davenport was later included in the Cedar Valley Limestone, whereas the Lower Davenport was changed to simply the Davenport Limestone Member.

In a comprehensive discussion of the stratigraphic relationships, nomenclature, and paleontology of the Devonian rocks in the north-central United States, Collinson et al. (1967) stated that the Wapsipinicon Limestone extends from Iowa into northwestern Illinois where it wedges out onto the Sangamon Arch. They tentatively correlated the Wapsipinicon with the lower Lingle and Grand Tower Formations of central Illinois. James (1968) and Collinson and James (1968), in a more detailed stratigraphic and paleontological investigation of the Middle Devonian carbonates, traced the Wapsipinicon as far as DeWitt County, into the area of the coal occurrence where it overlaps onto the Sangamon Arch. James (1968, pl. 3) constructed a paleoecological map of the top of the Wapsipinicon in Illinois that shows the distribution of various lithologies, including the coal and coaly shale.

\section{PETROGRAPHIC DESCRIPTION OF THE SAMPLES}

The microstructure of the coal is characterized by different degrees of preferred particle orientation. Some horizons are well laminated, whereas others lack any preferred particle orientation. The percentage of spores and other organic matter increases with the degree of orientation. The well stratified portions contain between 40 and 75 volume percent organic matter (pl. 1, fig. 2). The layers that lack internal orientation of the particles contain only about 30 volume percent coaly material, which is made up almost entirely of vitrinite.

Sample no. 1 (text figs. 1 and 2, and table 1) represents the best development of coal in the three cored sections (pl. 1, fig. 1). It occurs 14 feet $(4.3 \mathrm{~m})$ below the top of the Wapsipinicon Limestone. The coal, which is a little more than one-half inch thick, is dull, fine grained, fractures conchoidally, and has a somewhat canneloid appearance. It is cut by several highly polished and slickensided horizontal and high-angle planes. The contact with the limestone is irregular and in part almost vertical (pl. l, fig. l). The limestone is medium to dark gray, 


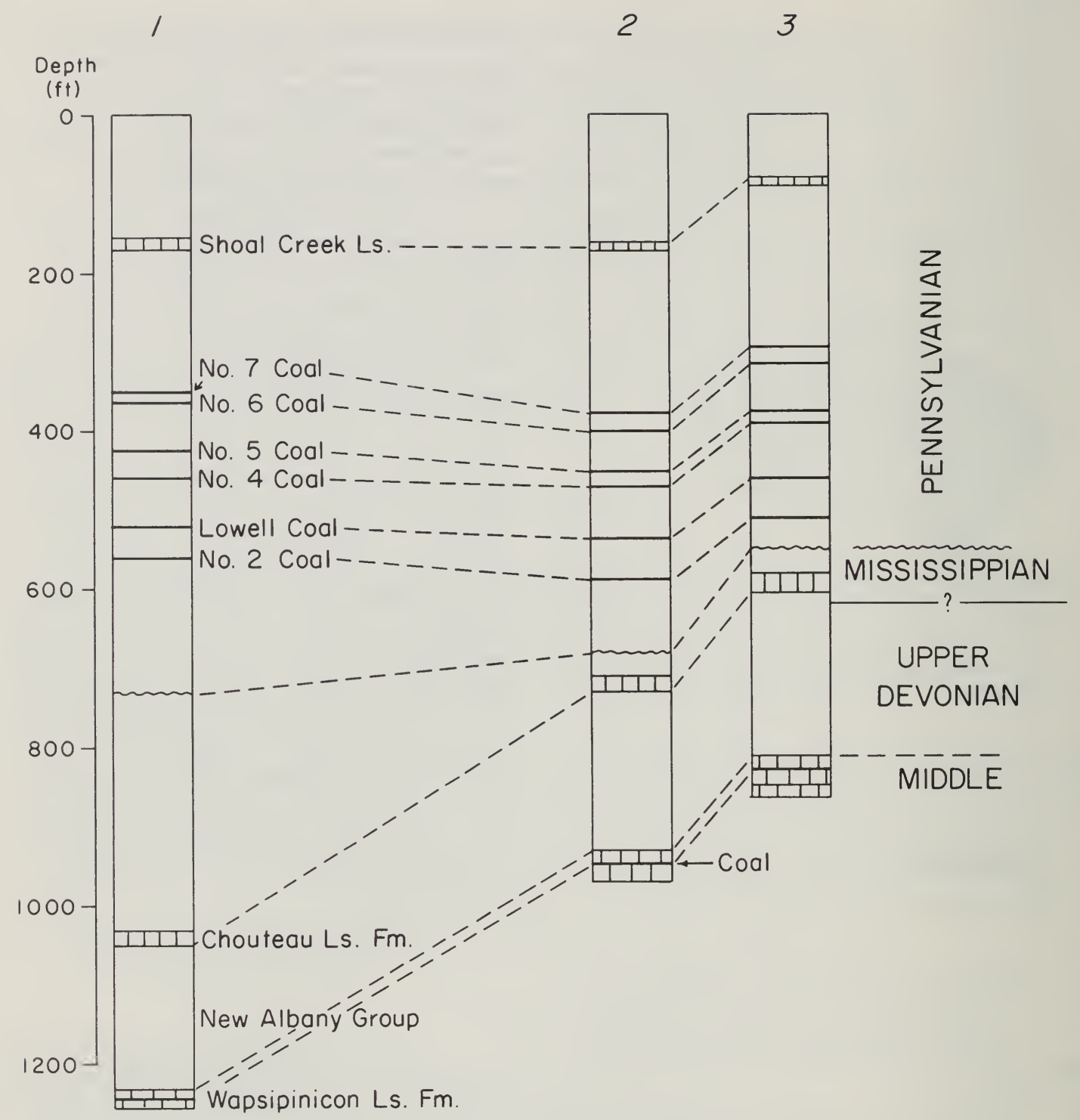

Text fig. 2 - Stratigraphic sections of boreholes in which Devonian coal was found (sample numbers refer to table 1 and text figure l).

dense, fine grained, and contains up to almost 50 percent fine quartz sand. The sand grains are rounded and well sorted as they are in many of the lower Paleozoic sandstones of the Illinois Basin.

A few small pieces of coal were taken from this sample, embedded in an epoxy pellet, and polished for microscopic examination.

The microlamination of the purer coal bands is mainly displayed by the orientation of vitrinite lenses (pl. 1, fig. 2). These generally range from 10 to $500 \mu$ in length and comprise 23 volume percent of the coaly material. Two-thirds of 
TABLE 1 - NAMES AND LOCATIONS OF DIAMOND DRILL CORES SAMPLED FOR STUDY

\begin{tabular}{|c|c|}
\hline Sample no. & Description \\
\hline 1 & $\begin{array}{l}\text { Maceration 1510, petrographic sample A-1014, chemical analysis } \\
\text { C-15776 - E. M. Self, Walden No. 1; SW } \frac{1}{4} \mathrm{NW}^{\frac{1}{4}} \mathrm{SE} \frac{1}{4} \mathrm{Sec} .24 \text {, T. } 21 \mathrm{~N} \text {. , } \\
\text { R. } 3 \text { E., DeWitt County; coal at } 1254 \text { feet }(382.2 \mathrm{~m}) \text { depth; I1linois } \\
\text { State Geological Survey file no. } 53810 \text {. }\end{array}$ \\
\hline 2 & $\begin{array}{l}\text { Maceration } 1548 \text {, petrographic sample A-1275 - Earl P. Pinney Com- } \\
\text { pany, Berenz-Hanover Farm Trust No. 1; } 330 \text { feet N line, } 330 \text { feet } \\
\text { W line, NW/ Sec. 25, T. } 23 \text { N., R. } 3 \text { E., McLean County; coal at } \\
945 \text { feet }(288.0 \text { m) depth; Illinois State Geological Survey file } \\
\text { no. C-4556. }\end{array}$ \\
\hline 3 & 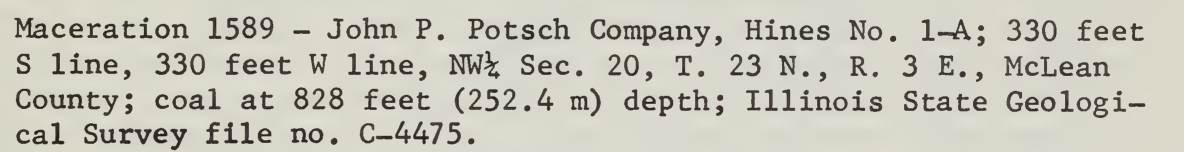 \\
\hline
\end{tabular}

the coaly material in the relatively pure coal occurs as fairly round or lenticular vitrinite particles, approximately $10 \mu$ or less in diameter.

About half of the vitrinite in the thin nonlaminated layers is irregularly shaped, apparently corroded, and larger than $10 \mu$ (pl. 1, fig. 3). The other half is made up of fragments that are often rounded and mostly smaller than $10 \mu$ (pl. 1, fig. 4). The vitrinite appears to have broken down along discrete irregu lar lines of weakness, which may coincide with former cell boundaries (pl. 1, fig. 5). Most of the vitrinite is free from mineral inclusions. However, disseminated pyrite occasionally occurs along what may have been vascular strands (pl. 1, fig. 6), and large spherical pyrite grains may occupy a portion of a vitrinite particle.

Exinite, which consists mainly of sporinite, is found mostly in the more pure and laminated parts of the coal. Ornamented and unornamented spores can be distinguished in polished sections. About half of them are larger than $150 \mu$. 'Large, usually very dark brown-gray spores, as shown in plate 2, figure 1, would probably be assigned to Tasmanites or Leiosphaeridia, as the se are the only unornamented spores of this size range that have been observed in the macerated residue (pl. 5, figs. 9-11). Most of the small spores are probably those referred to as algae (?) in the palynological section (pl. 5, figs. 13-14). The rest of the exinite is made up of very finely fragmented material whose composition could not be determined but which probably includes broken spores and possibly thin cuticles.

No resinite or waxes were observed, nor was fusinite or other inertinite recognized.

Pyrite is predominantly syngenetic, occuring as finely disseminated crystals of only a few microns in diameter that in places form aggregates of larger pyrite spheres, about $20 \mu$ in diameter (pl. 2, fig. 2). Only a few pyrite grains as large as $1 \mathrm{~mm}$ were found. Pyrite makes up 8 to 9 volume percent of Sample no. 1. Some small crystals of sphalerite were also observed in this sample.

Single or occasionally twinned quartz crystals that occur in the coal are fairly well rounded and are up to $20 \mu$ in diameter (pl. 2, fig. 3). The quartz makes up about 5 percent by volume of the coaly material and is distributed throughout. It is similar to the quartz in the sandy limestone in which the coal was found. 
Lenses of fine-grained limestone are interbedded with the coal. Calcitic shell fragments are also common.

The very fine-grained groundmass, which makes up 40 to 60 volume percent of the coal of Sample no. 1, is mainly composed of argillaceous limestone but contains an estimated 20 to 40 volume percent of very finely dispersed coaly material.

Sample no. 2 (text figs. 1 and 2, and table 1) is from a 3 -inch "dark carbonaceous shale" (driller's report). Only 0.8 inches $(2.0 \mathrm{~cm})$ of it had been collected during routine sampling, and no orientation was noted.

A band about 0.4 inches thick is darker, brighter, better laminated, and contains more vitrinite than the rest of the coaly material (pl. 2, fig. 4). This band is similar in composition to that of the laminated coal of Sample no. 1, but the microstratification is not quite as well developed. The vitrinite lenses show a higher degree of degradation. The spores are often broken. Less pyrite, mostly as subhedral crystals rather than fine syngenetic grains, and a larger proportion of fine-grained groundmass than in Sample no. 1 are characteristic of Sample no. 2.

The amount of coal in the limestone decreases away from the coaly layer in Sample no. 2. A thin transitional zone is composed mainly of closely packed angular dolomite grains, limestone lenses, and many shell fragments. In the interstices between these particles, coal and a fine-grained groundmass of coal, pyrite, and limestone occur. The transition zone may represent reworking of earlier deposited sediments (pl. 2, fig. 5).

The brownish gray limestone in this coal is silty and contains scattered pyrite grains and broken fossil fragments up to $4 \mathrm{~mm}$ long that are irregularly dis persed in a fine-grained calcitic matrix. A few thin carbonaceous partings occur near the contact of the coal. Microstylolites are very common along these partings (pl. 2, fig. 6). The limestone is composed of fairly angular calcitic grains of a medium to fine sand size. The grain boundaries are usually not sharp, and many of them show secondary growth.

Sample no. 3 is similar to Sample no. 2. The coaly layer, 0.75 inch $(1.9 \mathrm{~cm})$ thick, is sharply delineated from the underlying and overlying light gray to brown limestone. Shell fragments, which can be seen with the unaided eye, are more common than in the first two samples. The silty, mainly fine-grained limestone contains thin carbonaceous partings.

\section{COALIFICATION AND CHEMICAL ANALYSIS}

The rank of an Illinois coal is normally determined by analysis of its moist but mineral matter-free calorific value expressed in Btu per pound. A high ash content, as in this Devonian coal, decreases the reliability of the mineral matter-free calculated calorific value. Also, the coal has undergone considerable drying before the analysis was made, so that the 0.9 percent moisture (table 2) may not represent the true bedrock value needed to determine rank according to ASTM Standard D 388-66. One parameter of coalification, which is widely used among coal petrographers and is applicable to this particular coal, is the reflectance as measured in oil immersion $\left(R_{0}\right)$ on a highly polished surface. Because vitrinite is the principal and most homogeneous constituent of most bituminous coals, it is normally used for reflectance measurements to determine the level of coalification. The reflectance of vitrinite, in general, increases gradually with increasing rank of a coal. 
TABLE 2 - CHEMICAL ANALYSIS OF PORTION OF SAMPLE NO. 1

(Lab No. C. - 15 776)

\begin{tabular}{|c|c|c|c|c|}
\hline & & $\begin{array}{l}\text { As } \\
\text { received }\end{array}$ & $\begin{array}{l}\text { Moisture } \\
\text { free }\end{array}$ & $\begin{array}{l}\text { Moisture } \\
\text { and } \\
\text { ash free }\end{array}$ \\
\hline Proximate analysis & $\begin{array}{l}\text { Moisture } \\
\text { Ash }\end{array}$ & 32.9 & 32.3 & \\
\hline U1timate analysis & $\begin{array}{l}\text { Hydrogen } \\
\text { Carbon } \\
\text { Nitrogen } \\
\text { Oxygen } \\
\text { Sulfur } \\
\text { Ash }\end{array}$ & $\begin{array}{r}4.0 \\
51.7 \\
.8 \\
4.3 \\
7.2 \\
32.0 \\
\end{array}$ & $\begin{array}{r}4.0 \\
52.2 \\
.8 \\
3.6 \\
7.2 \\
32.2 \\
\end{array}$ & $\begin{array}{r}5.9 \\
77.0 \\
1.2 \\
5.2 \\
10.7\end{array}$ \\
\hline Total & & 100.0 & 100.0 & 100.0 \\
\hline $\begin{array}{l}\text { Low-temperature } \\
\text { ashing }\end{array}$ & $\begin{array}{l}\text { Mineral } \\
\text { matter }\end{array}$ & 43.0 & & \\
\hline
\end{tabular}

The reflectance of vitrinite grains in oil immersion from Sample no. 1 var ies between 0.60 and 0.85 percent. The larger vitrinite lenses of more than approximately $100 \mu$ in diameter have a 0.04 to 0.06 percent higher reflectance than the smaller ones. The average reflectance of all vitrinite macerals measured was calculated at $\mathrm{R}_{\mathrm{O}}=0.74$ percent, which corresponds to vitrinite reflectance from coal with 14,000 to $14,700 \mathrm{Btu} / \mathrm{lb}$ on a moist, mineral matter-free basis (Illinois State Geological Survey unpublished data-high volatile A coal).

All Pennsylvanian coals in central Illinois have a somewhat lower rank (high volatile C). The gradients of increase of calorific or reflectance values by depth, however, cannot be determined with satisfactory accuracy because of the lack of other samples in the area of these three boreholes.

The spores in this Devonian coal are very dark. Two kinds could be distinguished: the brownish gray, very dark large spores that have a reflectance $\left(R_{O}\right)$ between 0.07 and 0.13 percent (average of 0.11 percent) and the somewhat lighter and usually smaller spores with $R_{0}$ between 0.20 and 0.27 percent (average of 0.24 percent). The difference of 0.5 to 0.6 percent between the spores and the vitrinite of this coal is typical for high volatile bituminous coals. In medium and low volatile bituminous coals, spores have only a slightly lower reflectance than vitrinites.

Several small pieces of coal (a total of $9.8 \mathrm{~g}$ ) that had broken off the core of Sample no. 1 were analyzed and submitted for low-temperature ashing to determine the minerals in the coal (H. J. Gluskoter, 1965) (table 2).

Of the 7.2 percent sulphur, probably 5 to 6 percent is pyritic sulphur (pyrite equivalent 9 to 11 percent), which must be added to the ash for total mineral matter value. The difference between the approximately 38 percent mineral matter thus calculated and the 43 percent mineral matter measured by low-temperature ashing is primarily due to the loss of $\mathrm{CO}_{2}$ (carbonates.) and $\mathrm{SO}_{2}$ (pyrite) during the 
normal high-temperature ashing, which converts most of the minerals to oxides. Some weight is regained through oxidation of iron to $\mathrm{Fe}_{2} \mathrm{O}_{3}$. The 8 to 9 volume percent of pyrite determined from the petrographic analysis corresponds to approximately 20 weight percent pyrite, which is somewhat higher than the chemical analysis indicates. However, rather impure pyrite-rich layers of coal were included in the petrographic analysis, whereas the pieces that were submitted for chemical analysis had less pyrite.

The unusually low 5.2 percent oxygen on the moisture- and ash-free basis, which would normally be found in a medium volatile bituminous coal, indicates that the results of the ultimate analysis are not necessarily representative for the pure organic matter of this coal.

V. E. Dow (1960, p. 255) described similar properties for a thin, slightly younger coal in the Cedar Valley Limestone from three outcrops in Johnson County, Iowa: thinly laminated, abundant carbonaceous material (40 to 50 percent in one sample), pyrite that had been altered to limonite, and a large amount of ash (25 percent, as calculated on the same basis as the Illinois coal). Dow observed 85 to 90 percent spore exines in one thin section parallel to the bedding. The proportion of exinite observed in a polished section of a sample of the weathered Iowa coal that we prepared is more than that of the Illinois coal but is well below Dow's value. Dow also mentioned "some yellow-orange bodies of what appears to be resin" in one of his thin sections, and "fish remains (plates, teeth, etc.)."

\section{PALYNOLOGY}

Although published investigations of Devonian palynology have increased considerably in the last few years, this report is only the second concerning Devonian land plant spores in Illinois. Guennel in 1963 described Devonian spores from a Silurian reef cored by a diamond drill in southern Illinois. The spores, many of which were described as new, were from cavity fillings of strata younger than the reef. Other publications on Devonian-dispersed land plant spores in the United States are almost as scarce as those in Illinois. A monographic work on the plant spores and other microfossils from Upper Devonian and Lower Mississippian rocks of Ohio was prepared by Winslow in 1962. Kosanke (1964, p. 78-79), in a discussion of applied Paleozoic palynology, briefly mentioned the presence of spores in a coal from the Cedar Valley Limestone of Johnson County, Iowa. Sanders (1967) described in detail the spores from this coal. This is the only other known report of spores from a Devonian coal in the United States.

The Solon Limestone Member of the Cedar Valley Limestone has provided an extensive spore assemblage (Norton, 1967) and a new spore genus (Urban, 1968). McGregor (1960, 1961, 1964, and 1967) and McGregor and Owens (1966) have contributed a large amount of significant data on the Devonian spores of Canada. Numerous major contributions to the knowledge of Devonian palynology come from othor parts of the world, but no attempt is made to review them here.

\section{Maceration Technique}

Samples no. 1 and 2 (macerations 1510 and 1548) were treated for about 4 hours with 10 percent solution of hydrochloric acid to remove the carbonate minerals, and after decanting several times, hydrofluoric acid was added to remove most of the silicate minerals. These steps were omitted for Sample no. 3 (maceration 1589). 
Following oxidation of the three samples in Schulze's solution (1 part saturated potassium chlorate solution to 2 parts concentrated nitric acid) for about 5 days, the liquid was neutralized by repeated changes of water. Treatment with 5 percent solution of potassium hydroxide for about 10 minutes was used to free the spores from the other constituents.

When the humic matter had been completely removed, the residue was sieved through a 65 -mesh Tyler screen with openings of $210 \mu$ to remove the coarse fragments. A portion of the fine fraction was dehydrated in alcohol and a 50 percent alcohol-50 percent xylol solution and mounted with liquid Canada balsam on microscope slides for examination. A Spencer Microstar microscope (serial no. 417297) was used for locating by coordinates the individual spores on the slides. All slides are deposited in the Illinois State Geological Survey paleobotany collection.

\section{DESCRIPTIVE PALYNOLOGY}

Plant Spores

Genus PUNCTATISPORITES (Ibrahim) Potonie and Kremp, 1954

Type species.-P. punctatus (Ibrahim) Potonie and Kremp, 1954.

\section{Punctatisporites solidus Hacquebard, 1957}

\section{Plate 3 , figure 1}

Discussion.-Except for the slightly more circular outline of the two specimens observed in this investigation, they conform to the description and illustration of this species given by Hacquebard.

$$
\underline{\text { Punctatisporites }} \frac{\text { glaber (Naumova) Playford, } 1962}{\text { Plate 3, figure 2 }}
$$

Punctatisporites cf. irrasus Hacquebard, 1957 Plate 3 , figure 3

Discussion.-Hacquebard (1957, p. 308) reported a size range of 67 to $83 \mu$ for P. irrasus, but Sullivan (1964, p. 1251) and Doubinger and Rauscher (1966, p. 366) included spores with a minimum size limit of 56 and $52 \mu$, respectively. The maximum dimension of the Illinois specimen is $61.8 \mu$.

Punctatisporites aerarius Butterworth and Williams, 1958

Plate 3 , figure 4

Punctatisporites $\mathrm{sp}$.

Plate 3 , figure 5 
Description.- The spores are radial, trilete, and circular to subcircular in outline. The rays are distinct, straight, and extend about two-thirds the length of the spore radius. The well developed area contagionis is thicker and darker than the rest of the exine, which is about $\overline{3 \mu}$ thick. The spore wall is very finely scabrate to punctate. Maximum diameter of spores (2 specimens) is 100 and $90.4 \mu$.

Comparison.-Except for the prominent area contagionis, this species is very similar to $\underline{\mathrm{P}}$. aerarius Butterworth and Williams, 1958.

Genus CALAMOSPORA Schopf, Wilson, and Bentall, 1944 1944).

Type species.-‥ hartungiana Schopf (in Schopf, Wilson, and Bentall, Calamospora atava (Naumova) McGregor, 1964

Plate 3, figure 6

Genus RETUSOTRILETES (Naumova) Streel, 1964

Type species.-R. Simplex Naumova, 1953.

Retusotriletes cf. simplex Naumova, 1953

Plate 3, figure 7

Discussion.-The maximum size of $\mathrm{R}$. simplex of $35 \mu$, given by Naumova (1953), was extended upward to 61 and $65 \mu$ by de Jersey (1966) and Schultz (1968), respectively. The spore illustrated in this report is also considerably larger $(64 \mu)$ and thinner than the spores described by Naumova. Until more data become available, this larger form, which may represent a different species, is only compared with $\underline{\text { R. simplex. }}$

Retusotriletes obscurus Peppers sp. nov. Plate 3 , figures $8-9$

Description.- The spores are radial, trilete, and circular to subcircular in outline. The rays are distinct, often sinuous, and extend one-half to two-thirds the distance to the spore margin. The raised lips are about $3 \mu$ wide and are darker and thicker than the rest of the spore coat. The curvaturae are visible but not conspicuous. The exine is laevigate and infra-punctate. The exine is 3.5 to $6 \mu$ thick. Size range (20 specimens): 83.5 to $126.8 \mu$; median, $102 \mu$.

Holotype.-Plate 3, figure 8; maceration 1510, slide 4, coordinates 141.0 x 42.3; size, 102.1 by $94.3 \mu$.

Paratype.-Plate 3, figure 9; maceration 1510, slide 7, coordinates 127.6 x 52.5 ; size, 126.8 by $120.3 \mu$. 
Etymology.-The specific name refers to the rather inconspicuous curvaturae of this taxon.

Retusotriletes striatus Peppers sp. nov.

Plate 3 , figures $10-13$; text figure 3

Description.-The spores are radial, trilete, and roundly triangular in outline but often folded or partially torn. The indistinct rays are simple, straight, and extend about two-thirds the distance to the spore margin. The curvaturae are thin, indistinct, and sometimes visible only with oil immersion objective. The contact area is laevigate and thinner than the distal and equatorial areas. Marginal and transverse to the curvaturae are approximately 100 very fine, closely spaced striations and ridges, 5 to $8 \mu$ long and less than $1 \mu$ wide, which may not be visible when viewed with high dry objective. The ridges gradually merge into rows of grana, which in turn merge poleward toward a random distribution of grana that cover the distal and equatorial areas of the exine. The sharply defined grana, which are circular in plan view, are widely spaced, of about equal size, and less than $1 \mu$ in diameter. Thickness of the exine is 1 to $2 \mu$. Size range (18 specimens): 47.8 to $68.6 \mu$; median, $59 \mu$.

Holotype.-Plate 3, figure 10; maceration 1510, slide 11, coordinates 141.2 x 34.0 ; size, 55.3 by $51.0 \mu$.

Paratypes.-Plate 3, figure 11; maceration 1510, slide 12, coordinates $122.8 \times 33.3$; size, 54.9 by $43.9 \mu$. Plate 3 , figure 12 ; maceration 1510 , slide 16 , coordinates $133.3 \times 47.5$; size, 60.8 by $45.5 \mu$. Plate 3 , figure 13; same specimen as figure 11 but at $1000 X$ magnification to show part of curvaturae.

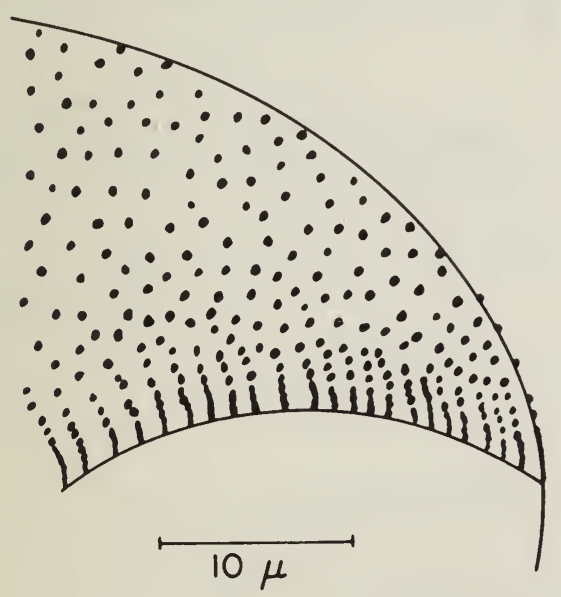

Text fig. 3 - Portion of Retusotriletes striatus to show ridges adjacent to curvatura and ornamentation on distal surface.
Etymology.-The specific name refers to the short ridges and striations around the curvaturae.

Retusotriletes tenerimedium

Chibrikova, 1959

Plate 3, figure 14

Retusotriletes sp.

Plate 3, figure 15

Description.-The spore is radial, trilete, and subcircular in transverse plane. The trilete rays are distinct, extend about two-thirds the length of the spore radius, and are bordered by elevated, wavy lips. The curvaturae are conspicuous, thickened, and about $5 \mu$ wide. The surface of the exine is vermiculate and obvermiculate, but in the area enclosed by the curvaturae, the 
ornamentation is finer. The spore coat is about $2 \mu$ thick. The diameter is 70.5 by $61.8 \mu$.

Genus APICULATASPORITES (Ibrahim) Smith and Butterworth, 1967

Type species._- . spinulistratus (Loose) Ibrahim, 1933.

Apiculatasporites wapsipiniconensis Peppers sp. nov. Plate 4 , figures $1-2$; text figure $4 \mathrm{~A}$

Description.-The spores are radial, trilete, and circular to subcircular in outline but are almost always folded. The distinct rays are somewhat sinuous and extend about two-thirds the distance to the spore margin. The commissure is bordered by lips up to $2 \mu$ wide. The exine is ornamented with cones or spines that are one to two times as long as they are wide; the longest are mostly sharply pointed and bent but are occasionally broken at the ends. The basal diameter of the projections and the spacing between them is less than $1 \mu$; between 120 and 140 can be counted at the spore margin. The spore coat is 1 to $2 \mu$ thick. Size range (15 specimens): 64.7 to $98.8 \mu$; median, $77 \mu$.

Holotype.-Plate 4, figure 1; maceration 1548, slide 3, coordinates 140.0 x 51.6 ; size, 73.8 by $69.9 \mu$.

Paratype.-Plate 4, figure 2; maceration 1510, slide 2 , coordinates $127.6 \times 45.1$; size, 71.5 by $61.8 \mu$.

Comparison.-Apiculatasporites wapsipiniconensis compares most closely to $\underline{A}$. dilucidus (McGregor) McGregor, 1964, but the latter has a smaller size range (50 to $69 \mu$ ), is seldom folded, and has fewer (75 to 124) projections at the margin that are apparently shorter than those on A. wapsipiniconensis. McGregor (1964, p.14-15) discussed other species that are somewhat similar to $\underline{A}$. dilucidus.

Etymology.-The specific epithet is named for the Wapsipinicon Limestone.

Apiculatasporites davenportensis Peppers sp. nov.

Plate 4 , figures $3-4$; text figure $4 \mathrm{~B}$

Description.-The spores are radial, trilete, and elliptical to circular

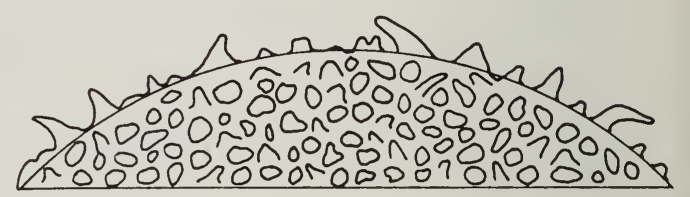

A

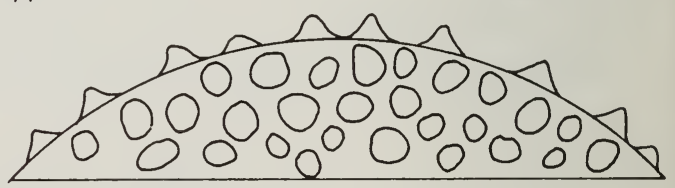

B

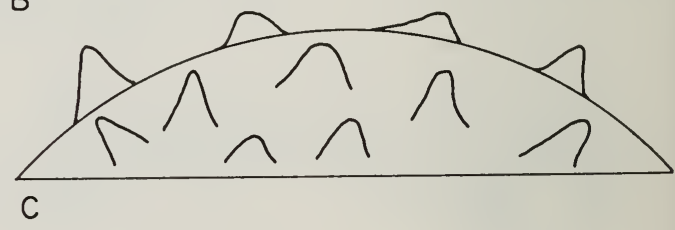

$10 \mu$

Text fig. 4 - Portions of spore exines to show ornamentation of (A) Apiculatasporites wapsipiniconensis, (B) A. davenportensis, and (C) $\underline{A}$. dewittensis. 
in outline but almost always folded. The commissure is indistinct or not visible because of the ornamentation. The rays are simple, straight, and extend about one-third the length of the radius. The exine is covered with very small coni that are about uniform in size and less than $1 \mu$ in height and width. The coni almost touch at their bases. About 80 extend beyond the spore margin, but even under oil immersion objective, the number is very difficult to count. The exine is less than $1 \mu$ thick. Size range (10 specimens): 27.6 to $39.3 \mu$; median, $33.5 \mu$.

Holotype.-Plate 4, figure 3; maceration 1510, slide 13, coordinates 135.0 x 36.0 ; size, 31.2 by $28.6 \mu$.

Paratype.-Plate 4, figure 4; maceration 1510, slide 19; coordinates 142.8 x 57.3 ; size, 33.8 by $31.2 \mu$.

Etymology.-The species is named for the Davenport Member of the Wapsipinicon Limestone.

\section{Apiculatasporites dewittensis Peppers sp. nov.} Plate 4 , figures $5-6$; text figure $4 \mathrm{C}$

Description.-The spores are radial, trilete, and elliptical to circular in outline. The commissure is very indistinct and often not visible. The trilete rays are straight, simple, and extend almost to the equator. The proximal and distal surfaces are covered with coni, about as high as they are wide, but several coni may have a length one and one-half times more than their width. The coni are about $1 \mu$ in diameter at their bases and are 1.5 to $2 \mu$ apart. Between 30 and 40 coni can be counted at the spore margin. The exine is about $1 \mu$ thick. Size range (10 specimens): 23.1 to $35.1 \mu$; median, $27.6 \mu$.

Holotype.-Plate 4, figure 5; maceration 1510, slide 8; coordinates 131.8 x 31.5 ; size, 28.6 by $26 \mu$.

Paratype.-Plate 4, figure 6; maceration 1510, slide 27; coordinates 140.4 x 49.5 ; size, 23.1 by $19.5 \mu$.

Comparison.-A. dewittensis has larger, more widely spaced coni than $\underline{A}$. davenportensis $\mathrm{sp}$. nov.

Etymology.-This species is named for DeWitt County, Illinois.

Genus ACANTHOTRILETES (Naumova) Potonié and Kremp, 1954

Type species.-A. ciliatus Potonié and Kremp, 1954.

Acanthotriletes uncatus Naumova, 1953 Plate 4 , figure 7

Acanthotriletes cf. polyganius Naumova, 1953

Plate 4 , figure 8 
Description.-The spores are radial, trilete, circular to subcircular in outline, and seldom folded. The commissure and trilete rays are very indistinct due to the nature of the ornamentation. The rays are straight, lack lips, and extend about two-thirds the distance to the margin. The exine is covered with spines up to $3 \mu$ long, but their size varies considerably. They are one to two times as long as they are wide, and many are curved. They are not evenly distributed but are generally 2 to $3 \mu$ apart. Between 40 and 60 spines are at the spore margin. The exine has an over-all shaggy appearance and is about $1 \mu$ thick. Size range (10 specimens): 38.7 to $46.5 \mu$; median, $42.3 \mu$.

Comparison.-A comparison between the Illinois spores and the ones studied by Naumova is difficult because of the brevity of her description. According to the emendation of Acanthotriletes by Potonié and Kremp (1954), the spines on these spores should be at least twice as long as they are wide. However, the spines on the Illinois specimens are seldom that long, and Naumova (1953) did not state the dimensions of the spines on her spores.

\section{Genus EMPHANISPORITES McGregor, 1961}

Type species.-E. rotatus McGregor, 1961

Emphanisporites rotatus McGregor, 1961 Plate 4 , figure 9

Genus LYCOSPORA (Schopf, Wilson, and Bentall) Potonié and Kremp, 1954

Type species.-L. micropapillata (Wilson and Coe) Schopf, Wilson, and Bentall, 1944 .

\section{Lycospora pseudomagnifica Peppers sp. nov. Plate 4 , figures $10-12$}

Description.-The spores are radial, trilete, and roundly triangular when viewed in proximal-distal orientation. They are rarely folded, but the proximal spore surface is sometimes torn. The margin is straight to irregularly undulating. The commissure is visible, and the trilete rays are simple, occasionally undulating, and extend to the inner margin of the cingulum. A prominent, continuous flange or cingulum extends from the proximal surface just poleward of the equator. The cingulum is 5 to $9 \mu$ wide and is unornamented. The proximal surface of the spore is laevigate, but the distal surface is covered with low, elongated verrucae that are closely spaced and in places are joined or partly joined to form short ridges. The verrucae are 3 to $5 \mu$ in diameter and extend about $2 \mu$ above the spore surface. Spines and grana are absent. The proximal surface is about $2.5 \mu$ thick, and the distal surface is about $4 \mu$ thick. Size range (14 specimens): 58.5 to $83.2 \mu$, including cingulum; median, $67.3 \mu$.

Holotype.-Plate 4, figure 10; maceration 1510, slide 21, coordinates $138.6 \times 37.5$; size, 69.9 by $58.5 \mu$. 
Paratype.-Plate 4, figure 11; maceration 1510, slide 22, coordinates $128.5 \times 38.3$; size, 63.4 by $52.0 \mu$.

Tetrad.-Plate 4, figure 12; maceration 1510, slide 23, coordinates 143.3 x 49.5 ; size, 82.9 by $80.3 \mu$.

Comparison.-L. pseudomagnifica has an over-all appearance similar to that of L. magnifica McGregor, 1960, except that the latter has thickened lips and small coni and grana, and its surface is scabrate to finely punctate-vermiculate.

Etymology.-The specific name of this species suggests its resemblance to Lycospora magnifica McGregor, 1960.

\section{Lycospora sp. Plate 4, figure 13}

Description.-The spore is radial, trilete, and roundly triangular in outline. The commissure is indistinct, and the simple rays extend to the inner margin of the cingulum. The well developed cingulum is about $6.5 \mu$ wide and extends from the proximal surface. The exine is finely punctate; the punctations are up to $1 \mu$ in diameter and $2 \mu$ apart. The proximal side is $2.6 \mu$ thick, and the distal side is $3.3 \mu$ thick. The size is 66.6 by $50.4 \mu$ (including cingulum).

Genus SPELAEOTRILETES Neves and Owens, 1966

Type species.-S. triangulus Neves and Owens, 1966.

Spelaeotriletes sp.

Plate 4, figures $14-16$

Description.-The spores are radial, trilete, and roundly triangular in outline. The spore margin is partly uneven. A commissure is not visible, but the trilete rays are distinguished by thin folds, about $4 \mu$ wide, that extend almost to the spore equator. The central portion (intexine) of the spore, whose radius is about two-thirds the total radius, is well delineated and about the same thickness as the rest of the spore. The exine is infra-punctate to infra-vermiculate. On the distal side are rounded, elongated verrucae that gradationally increase in size and packing toward the pole. The largest verrucae are about $7 \mu$ in diameter, and they are occasionally joined at their bases. Most verrucae bear thin spines at their apexes. The sharply pointed spines are strongly curved toward the ends and are up to $7 \mu$ long. Size range (3 specimens): 91.0 to $122.9 \mu$.

Genus SPINOZONOTRILETES (Hacquebard) Neves and Owens, 1966

Type species.-S. uncatus Hacquebard, 1957. 


\section{Spinozonotriletes cf. tuberculatus Neves and Owens, 1966 Plate 5, figure 1}

Discussion.-The Illinois spores have a larger size range (110.5 to $183.6 \mu$ on 20 specimens) than that reported by Neves and Owens (90 to $136 \mu$ ) for this species. However, because our specimens generally conform in other respects to the British spores, they are assigned to this taxon.

\section{Spinozonotriletes cf. naumovii (Kedo) Richardson, 1965 Plate 5 , figure 2}

Discussion.-Apparently the principal differences between $\underline{S}$, naumovii and S. tuberculatus Neves and Owens, 1966, are that the former has a thicker intexine and smaller spines.

\section{Spinozonotriletes (?) sp.} Plate 5, figure 3

Description.-The spore is radial, trilete, and roundly triangular in outline. A commissure is not apparent, but the rays that are delineated by prominent lips or folds extend almost to the spore margin. The exine is in two parts-a thin central region that extends to about one-third the spore radius and a thick zona or cingulum that gradually tapers in thickness toward the equator. No intexine is visible. Under oil immersion objective the exine is infra-punctate and presents a spongy appearance. On the entire distal side are moderately spaced large spines, 16 to $23 \mu$ long and 5 to $8.5 \mu$ wide at their bases. They have tapered to sharply pointed ends. Approximately 32 of these spines extend beyond the spore periphery. The diameter is 195 by $177 \mu$.

\section{Genus ARCHAEOZONOTRILETES (Naumova) Allen, 1965}

Type species.-A. variabilis Naumova, 1953.

Archaeozonotriletes cf. purus Naumova, 1953

Plate 5, figure 4

Description.-The spore is radial, trilete, and circular in outline. The laesurae are distinct, simple, and extend almost to the margin of the central area or intexine, which is obliquely displaced. The exine is laevigate and infra-punctate. The distal side is only slightly thicker than the proximal size. The over-all diameter is 54.3 by $51.0 \mu$; the intexine is 44.5 by $41.3 \mu$.

Comparison.-Naumova's (1953) size range of 30 to $35 \mu$ is quite small compared with the Illinois spore. However, it is not unreasonable to assume that the size range could be more than $5 \mu$. 
Description.-The spore is radial, trilete, and subcircular in outline. The straight laesurae possess lips about $2 \mu$ wide and extend about three-fourths the length of the radius. A patinate layer of uniform thickness covers the distal side and extends onto the proximal side about one-half the distance to the proximal pole. The proximal edge of the patina ends abruptly. The exine is infra-punctate. The diameter is 54.6 by $48.8 \mu$.

Genus RHABDOSPORITES Richardson, 1960

Type species.-R. langi (Eisenack) Richardson, 1960.

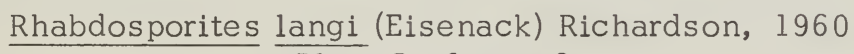

Plate 5, figure 6

Genus ANCYROSPORA Richardson, 1960

Type species.-A. grandispinosa Richardson, 1960.

Ancyrospora sp.

Plate 5, figure 7

Description.-The spore is radial, trilete, and possesses a bladder. The subcircular central body possesses straight rays that extend about three-fourths the distance to its periphery. The bladder bears numerous appendages that taper from a wide base to a narrow constriction and then abruptly expand just below the bifurcated ends. The appendages are 10 to $16 \mu$ long and 3 to $5 \mu$ wide at their bases. The spore is at least $130 \mu$ in over-all dimension and has a central body of $71 \mu$.

Discussion.-This spore and one fragment of another were the only specimens observed that display grapnel-shaped appendages. The fragmented specimen appeared to be thicker walled and may represent the genus Hystrichosporites McGregor, 1960.

Genus RETIALETES Staplin, 1960

Type species.-R. radforthii Staplin, 1960.

Retialetes sp.

Plate 5 , figure 8

Discussion.-This species is probably the same taxon described and designated as Retialetes sp. by Allen (1965, p. 741, pl. 106, figs. 3 and 4). 
Miscellaneous Microfossils

Genus LEIOSPHAERIDIA (Eisenack) Downie and Sarjeant, 1963

Type species.-L. baltica Eisenack, 1958.

\section{Leiosphaeridia sp.}

Description.-The plant microfossils are circular, often split open, usually partly corroded, and lack ornamentation. They are 18 to $23 \mu$ thick. Shallow circular pits with irregular margins, which may be due to bacterial action, are common. Size range (10 specimens): 322 to $465 \mu$.

Genus TASMANITES (Newton) Schopf, Wilson, and Bentall, 1944

Type species.-T. punctatus Newton, 1875.

Tasmanites huronensis (Dawson) Winslow, 1962

Plate 5, figures $10-11$

Genus VERYHACHIUM (Deunff) Downie and Sarjeant, 1963

Type species.-V. trisulcum Deunff, 1958

Veryhachium octoaster Staplin, 1961

Plate 5, figure 12

Algae (?)

Plate 5, figures $13-14$

Description.-The spore-like bodies are circular to subcircular, usually frequently folded, and often in small clusters of 6 or more individuals. They are laevigate but usually badly corroded. Generally, they are $1 \mu$ or less in thickness, but thickness often varies considerably on the same specimen. Size range is 22 to $45 \mu$ in diameter.

Discussion.-These spore-like bodies, which were abundant in all three macerations, are thought to have their affinities with the algae.

\section{Summary}

The spores are moderately well preserved, and the ratio of spores to fine fragments of organic debris is low. Maceration 1510 of Sample no. 1 (table 3) 
TABLE 3 - OCCURRENCE OF PLANT MICROFOSSILS IN THE THREE MACERATIONS STUDIED AND DISTRIBUTION (IN PERCENT) OF PLANT MICROFOSSILS IN MACERATION 1510.

\begin{tabular}{|c|c|c|c|}
\hline \multirow{2}{*}{ Spore taxa } & \multicolumn{3}{|c|}{ Macerations } \\
\hline & 1510 & 1548 & 1589 \\
\hline Punctatisporites solidus & $t^{*}$ & & \\
\hline P. glaber & + & & \\
\hline P. cf. irrasus & + & & \\
\hline P. aerarius & & $x^{1}$ & \\
\hline$\overline{\mathrm{P}} \cdot \overline{\mathrm{sp}}$ & & $\mathrm{x}$ & \\
\hline Calamospora atava & + & & \\
\hline Retusotriletes cf. simplex & + & & \\
\hline R. tenerimedium & & $\mathrm{X}$ & \\
\hline $\bar{R}$. obscurus & 7 & & \\
\hline R. striatus & 14 & & \\
\hline$\overline{\mathrm{R}} \cdot \mathrm{sp}$ & + & & \\
\hline Apiculatasporites wapsipiniconensis & 8 & $\mathrm{X}$ & \\
\hline A. davenportensis & 21 & $\mathrm{x}$ & \\
\hline A. $\overline{\text { dewittensis }}$ & 2 & & \\
\hline Acanthotriletes cf. polyganius & 13 & $\mathrm{x}$ & \\
\hline A. uncatus & + & & \\
\hline Emphanisporites rotatus & 5 & $\mathrm{X}$ & $\mathrm{X}$ \\
\hline Lycospora pseudomagnifica & 10 & & \\
\hline$\overline{\text { Lycospora sp. }}$ & + & & \\
\hline Spelaeotriletes sp. & + & $\mathrm{X}$ & \\
\hline Spinozonotriletes cf. tuberculatus & 16 & $\mathrm{X}$ & $\mathrm{X}$ \\
\hline S. cf. naumovii & + & $\mathrm{X}$ & \\
\hline sp. & + & & \\
\hline Archaeozonotriletes cf. purus & + & & \\
\hline A. $\mathrm{sp}$. & + & & \\
\hline Rhabdosporites langi & 4 & $\mathrm{X}$ & $\mathrm{X}$ \\
\hline Ancyrospora sp. & + & & \\
\hline Retialetes sp. & + & & \\
\hline Tasmanites huronensis & $\mathrm{x}$ & & \\
\hline$\overline{\text { Leiosphaeridia }}$ & $\mathrm{X}$ & & \\
\hline Veryhachium octoaster & & + & \\
\hline algae (?) & $\mathrm{x}$ & $\mathrm{x}$ & $\mathrm{x}$ \\
\hline
\end{tabular}

$*_{+}=$less than .1 percent

$\dagger_{\mathrm{X}}=$ percent not determined

yielded the largest diversity, whereas the assemblage with the poorest preservation and the least number of spores was found in maceration 1589 of Sample no. 3. Specimens of Acanthotriletes and Apiculatasporites show considerable corrosion and are sometimes difficult to distinguish from the circular bodies classified as algae (?). These latter forms were plentiful in all three macerations. A frequency distribution of the taxa in maceration 1510 reveals that Apiculatasporites, which accounts for 31 percent of the spore flora, is the dominant genus followed by Retusotriletes, with 21 percent, and Spinozonotriletes, with 16 percent. Lycospora (10 percent), Emphanisporites (5 percent), and Rhabdosporites (4 percent) are well represented. 
The value of a comparison between the spore assemblage of the Davenport Limestone Member and Devonian spore assemblages described from other regions is diminished by the small number of samples available. This assemblage also represents a restricted environment extending over a small geographic area during a geologically short time. A large number of Middle Devonian spore genera commonly reported by other workers are apparently lacking in this Illinois coal. These include Leiotriletes, Cyclogranisporites, Verrucosisporites, Stenozonotriletes, Densosporites, Geminospora, Auroraspora, Calyptosporites, and Grandispora. Also missing are many of the genera described in the most recent publications that may or may not prove to be of widespread occurrence as more data become available.

The Davenport assemblage is characterized by a predominance of small species of Apiculatasporites, which is followed in abundance by Retusotriletes and Spinozonotriletes. The assemblage differs considerably, even from the slightly younger Cedar Valley coal assemblage (Sanders, 1967) and the slightly younger Solon Member assemblage (Norton, 1967), both from Iowa. The only land plant spores common to the Cedar Valley and Davenport assemblages are Rhabdosporites langi, Punctatisporites atavus (Naumova) Sanders, 1967=(?) Punctatisporites sp., and possibly a species of Ancyrospora. The Iowa flora contains many more acritarchs (65 percent) than the Illinois flora, but no Tasmanites were observed in the former. The algal (?) fossils described and illustrated by Sanders (1967, pl. 3, figs. 1 and 2) are similar to those found in the Davenport coal.

\section{CONCLUSIONS}

According to Collinson et al. (1967, p. 936), during Middle Devonian time normal saline marine water of the Illinois Basin to the south and the very saline water of the basins in Michigan and Iowa were mostly separated by the Sangamon and Kankakee Arches. Evaporites and sandy carbonates were laid down in the Wapsipinicon Limestone to the north. During accumulation of the Davenport Limestone Member, toward the end of Wapsipinicon deposition, the sea had transgressed to a major extent onto the Sangamon Arch. Considerable evidence for this exists (James, 1968) and will be presented in another publication by Collinson and James. Near the strand line, along the northeastern margin of the Sangamon Arch, a diverse flora developed. The hydrophilous plants that contributed to the formation of the coal must have had very thin cuticles, as none could be positively identified. The plants were apparently small and delicate, as the vitrinite lenses rarely exceed $500 \mu$ in length and $50 \mu$ in thickness. Assuming a high compaction ratio of 20 to 1 , the thickness of the stems probably did not exceed a few millimeters.

The botanic remains that accumulated in this local environment were transported a short distance out to sea and were deposited under reducing saprophytic conditions, as indicated by the abundance of fine-grained syngenetic pyrite aggregates and the absence of oxygen-rich fusinite and other inertinite macerals. The fine lamination of the coaly bands suggests slow sedimentation in quiet water. Poorly sorted coal bands point to short periods of reworking and rapid resedimentation. The energy was sufficient to eliminate most of the spores, either by physical destruction or by winnowing.

Marine plant microfossils (Tasmanites, Leiosphaeridia, and Veryhachium) probably were incorporated in the coal as the plant material was floated out to sea 
and deposited in a shallow, nearshore environment suitable for the growth of marine organisms. Deposition near shore is also indicated by the quartz grains in the coal, and especially in the limestone, which contains the coal.

Only a small amount of plant debris was disseminated in the overlying and underlying silty to sandy lime mud. Thus, the coal and coaly shale represent a short episode in the geologic history of the Middle Devonian of central Illinois. It provides evidence, however, that a rather diversified flora existed near the beach in a period that was characterized by limestone deposition. 


\section{REFERENCES}

Allen, K. C., 1965, Lower and Middle Devonian spores of north and central Vestspitsbergen: Palaeontology, v. 8, pt. 4, p. 687-748.

Butterworth, M. A., and R. W. Williams, 1958, The small spore floras of coals in the Limestone Coal Group and Upper Limestone Group of the Lower Carboniferous of Scotland: Trans. Royal Soc. Edinburgh, v. 63, pt. 2, no. 17, p. 353-392.

Chibrikova, E. V., 1959, Spores from the Devonian and older rocks of Bashkiria: Acad. Sci. USSR, Bashkir. Filial, Moscow, p. 3-116.

Collinson, Charles, et al., 1967, Devonian of the north-central region, United States, in Oswald, D. H., ed., Internatl. Symposium on the Devonian System: Alberta Soc. Petroleum Geologists, Calgary, Alberta, Sept., v. l, p. 933-971.

Collinson, Charles, and A. T. James, 1968, Conodont zonation of the Devonian Cedar Valley Formation and the paleogeography of the Cedar Valley and Wapsipinicon Formations (abs.): Ann. Geol. Soc. America North-Central Sectional Meeting, Iowa City, Iowa, p. 42.

de Jersey, N. J., 1966, Devonian spores from the Adavale Basin: Geol. Survey of Queensland 334, Paleont. Papers, $28 \mathrm{p}$.

Deunff, Jean, 1958, Microorganismes planctoniques du Primaire Armoricain: Bull. de la Société Géologique et Mineralogique de Bretagne, Nouvelle Série, Fascicule 3, p. 1-41.

Doubinger, J., and R. Rauscher, 1966, Spores du Viséen marin de Bourbach-Le-Haut dans les Vosges du Sud: Pollen et Spores, v. VIII, no. 2, p. 361-405.

Dow, V. E., 1960, Some notes on the occurrence of a coal seam in the Cedar Valley Formation of Johnson County, Iowa: Proc. Iowa Acad. Science, v. 67, p. 253-259.

Downie, C., and W. A. S. Sarjeant, 1963, On the interpretation and status of some hystrichosphere genera: Palaeontology, v. 6, pt. 1, p. 83-96.

Eisenack, A., 1958, Tasmanites Newton 1875, and Leiosphaeridia n.g. als Gattungen der Hystrichosphaeridia: Palaeontographica, Bd. 110 A, p. 1-19.

Gluskoter, H. J., 1965, Electronic low-temperature ashing of bituminous coal: Fuel, v. 44, p. 285-291.

Guennel, G. K., 1963, Devonian spores in a Middle Silurian reef: Grana Palynologica, v. 4, no. 2, p. 245-261.

Hacquebard, P. A., 1957, Plant spores from the Horton Group (Mississippian) of Nova Scotia: Micropaleontology, v. 3, no. 4, p. 301-324.

Ibrahim, A. C., 1933, Sporenformen des Aegirhorizonts des Ruhr-Reviers: Konrad Triltsch, Wuerzburg, $47 \mathrm{p}$.

James, A. T., 1968, The Middle Devonian strata of northwestern Illinois and southeastern Iowa: Thesis for degree of Bachelor of Science, College of Liberal Arts and Sciences, University of Illinois, 22 p. 
Kosanke, R. M., 1964, Applied Paleozoic palynology: Palynology in oil exploration, a symposium: Soc. of Econ. Paleontologists and Mineralogists, Spec. Publ. 11, p. 75-89.

McGregor, D. C., 1960, Devonian spores from Melville Island, Canadian Arctic Archipelago: Palaeontology, v. 3, pt. 1, p. 26-44.

McGregor, D. C., 1961, Spores with proximal radial pattern from the Devonian of Canada: Geol. Survey Canada Bull. 76, 11 p.

McGregor, D. C., 1964, Devonian miospores from the Ghost River Formation, Alberta: Geol. Survey Canada Bull. 109, 31 p.

McGregor, D. C., 1967, Composition and range of some Devonian spore-assemblages of Canada: Rev. Palaeobotany and Palynology, v. 1, p. 173-183.

McGregor, D. C ., and Bernard Owens, 1966, Illustrations of Canadian fossils, Devonian spores of eastern and northern Canada: Geol. Survey Canada, Paper 66-30, $66 \mathrm{p}$.

Naumova, S. N., 1953, Spore-pollen complexes of the Upper Devonian of the Russian platform and their stratigraphic significance: Trans. Inst. Geol. Sci. Akad. Sci. USSR, V. 143 (Geol. Ser. 60), 204 p.

Neves, Roger, and Bernard Owens, 1966, Some Namurian camerate miospores from the English Pennines: Pollen et Spores, v. 8, no. 2, p. 337-360.

Newton, E. T., 1875, On "Tasmanite" and Australian "white coal": Geol. Mag., ser. 2, v. 2, no. 8, p. 337-342.

Norton, J. J., 1967, Palynomorphs from the Solon Member of the Cedar Valley Limestone of Iowa (abs.): Am. Jour. Botany, v. 54, no. 5, pt. 2, p. 650.

Norton, W. H., 1894, Notes on the lower strata of the Devonian series in Iowa: Iowa Acad. Sci., Proc. no. 1, pt. 4, p. 22-24.

Norton, W. H., 1895, Geology of Linn County, in Third Annual Report, 1894: Iowa Geol. Survey, v. 4, p. $121-195$.

Playford, Geoffrey, 1962, Lower Carboniferous microfloras of Spitsbergen-Part 1: Palaeontology, v. 5, pt. 3, p. 550-618.

Potonié, Robert, and Gerhard Kremp, 1954, Die Gattungen der palaeozischen Sporae dispersae und ihre Stratigraphie: Geol. Jb. 69, p. 111-194.

Richardson, J. B., 1960, Spores from the Middle Old Red Sandstone of Cromarty, Scotland: Palaeontology, v. 3, pt. 1, p. 45-63.

Richardson, J. B., 1965, Middle Old Red Sandstone spore assemblages from the Orcadian Basin, Northeast Scotland: Palaeontology, v. 7, pt. 4, p. 559-605.

Sanders, R. B., 1967, Devonian spores of the Cedar Valley coal of Iowa, U. S. A.: Jour. Palynology, v. 2 and 3, p. 17-32.

Schopf, J. M., L. R. Wilson, and Ray Bentall, 1944, An annotated synopsis of Paleozoic fossil spores and the definition of generic groups: Illinois Geol. Survey Rept. Inv. 91, 73 p.

Schultz, G., 1968, Eine unterdevonische Mikroflora aus den Klerfer Schichten der Eifel (Rheinisches Schiefergebirge): Palaeontographica, Bd. 123 B, p. 5-42. 
Smith, A. H. V., and M. A. Butterworth, 1967, Miospores in the coal seams of the Carboniferous of Great Britain: Special Papers in Palaeontology: Palaeontol. Assoc. London, no. 1, 324 p.

Staplin, F. L., 1960, Upper Mississippian plant spores from the Golata Formation, Alberta, Canada: Palaeontographica, Bd. 107 B, no. 1-3, p. 1-40.

Staplin, F. L., 1961, Reef-controlled distribution of Devonian microplankton in Alberta: Palaeontology, v. 4, pt. 3, p. 394-424.

Streel, M., 1964, Une association de spores du Givétien inférieur de la Vesdre, 'a Goé (Belgigue): Ann. Soc. Géol. de Belgique, v. 87, no. 7, p. 1-29.

Sullivan, H. J., 1964, Miospores from the Lower Limestone shales (Tournaisian) of the Forest of Dean basin Gloucestershire: Compte Rendu, Cinquième Congres International de Stratigraphie et de Géologie du Carbonifère, Tome III, p. 1249-1260.

Urban, J. B., 1968, Dibrochosporites, a new sporomorph from the Middle Devon-

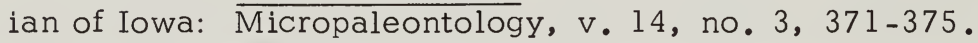

Winslow, M. R., 1962, Plant spores and other microfossils from Upper Devonian and Lower Mississippian rocks of Ohio: U. S. Geol. Survey Prof. Paper $364,93 \mathrm{p}$. 
PLATES

AND

EXPLANATIONS 


\section{PLATE 1}

Reflected plane polarized light, Ortholux Petrographic Microscope Polished surface of Sample No. 1

Figure

1. Portion of core containing Sample no. 1. Contact between coal and limestone is contorted and in part vertical. Slumping or squeezing in an early stage of diagenesis is indicated. Coal is interbedded with limestone lenses and shell fragments (light streaks in coal). Actual size.

2. Vitrinite lenses (V), up to $60 \mu$ thick and over $300 \mu$ long, embedded in a fine-grained groundmass. Exinite (E) is represented by small spores and probably fragments of larger spores, not over $20 \mu$ long. Pyrite (P) is disseminated throughout the coal mainly as fine grains of a few microns in diameter and a few aggregates up to $15 \mu$ in diameter. One large quartz grain $(Q)$ is in extinct position. Smaller quartz grains (extinct position black, nonextinct gray) occur throughout the coal but cannot be easily distinguished from coal or exinite. The fine-grained groundmass is composed of argillaceous limestone and finely disseminated coal. 25X oil immersion objective. Magnification: 250X.

3. The vitrinite (V) of this specimen without interior preferred orientation of the particles has an irregular and corroded appearance. No large spores are present, as in the internally laminated bands (pl. 2, figs. 1 and 2). Some small exinite fragments are among the black dots, but most of them are calcite grains in extinct position. Pyrite $(P)$ is somewhat less abundant than in the other photographs. One quartz grain (Q), 30 to $40 \mu$ in diameter, is seen. 25X oil immersion objective. Magnification: $250 \mathrm{X}$.

4. The vitrinite (V) of this coal without internal orientation occurs predominantly as round, small grains, less than $10 \mu$ in diameter. They were probably derived from larger pieces of vitrinite that disintegrated along such planes of weakness as shown in plate 1, figure 5. 105X oil immersion objective. Magnification: 1000X.

5. Part of a vitrinite lens with irregular cell (?) structure. The vitrinite grains tend to disintegrate along such planes of weakness into small vitrinite bodies less than $10 \mu$ across (pl. l, fig. 4). 105X oil immersion objective. Magnification: 1000X.

6. Fine-grained pyrite is disseminated in vitrinite along what probably were former vascular strands. Besides much fine-grained pyrite in the groundmass, one large pyrite grain is shown around which the laminae are bent. $60 \mathrm{X}$ oil immersion objective. Magnification: 600X. 

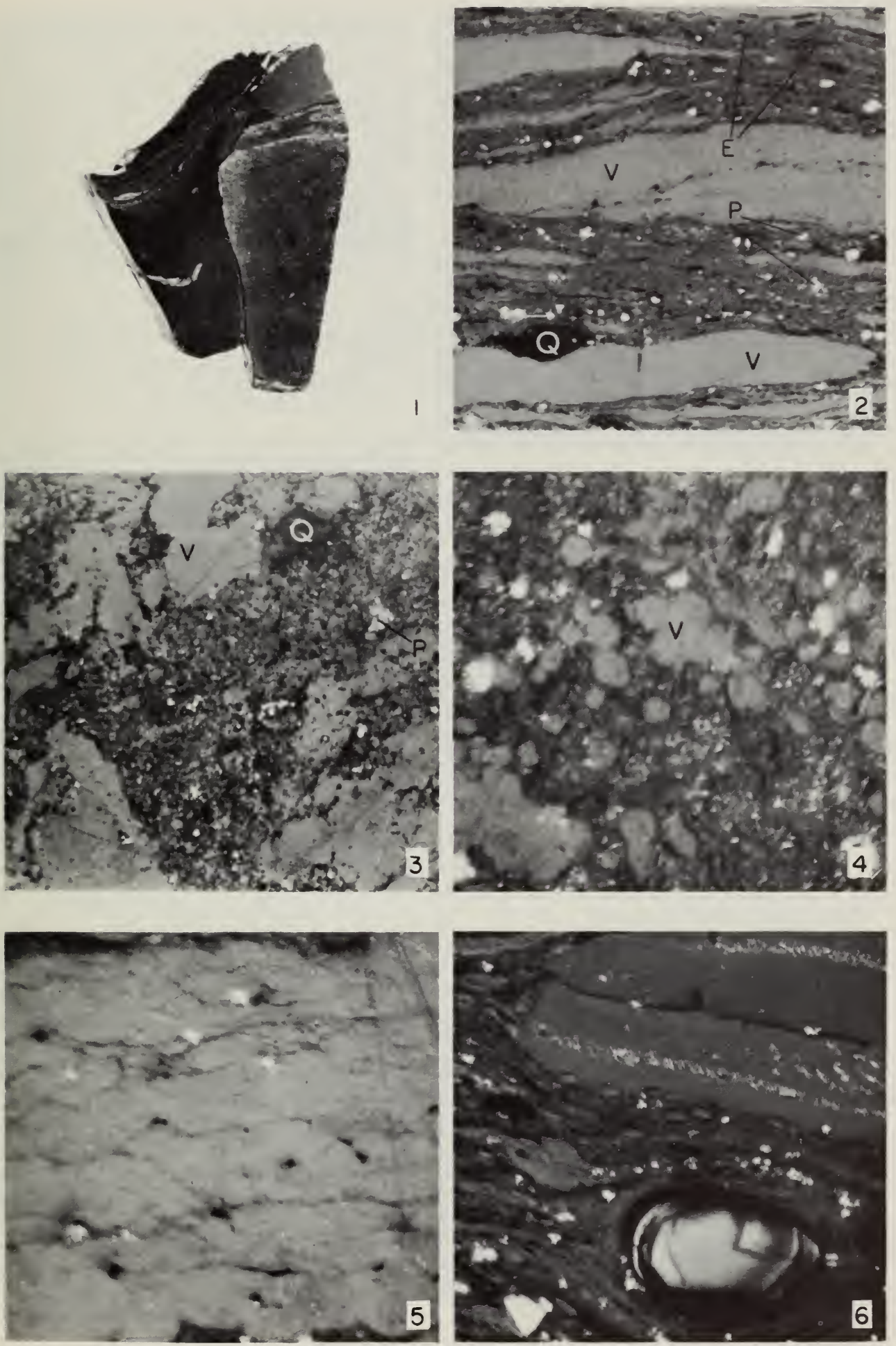


\section{PLATE 2}

Reflected plane polarized light, Ortholux Petrographic Microscope Polished surfaces of Samples no. 1 (figs. 1-3) and 2 (figs. 4-6)

Figure

1. Large, dark brown-gray spore, $300 \mu$ long and $22 \mu$ thick, and small vitrinite lenses (V) embedded in fine-grained groundmass. This spore is probably Tasmanites or Leiosphaeridia. Smaller spores also can be seen in this figure. $25 \mathrm{X}$ oil immersion objective. Magnification: $250 \mathrm{X}$.

2. Microstratified coal containing a large amount of pyrite $(P)$ that occurs both as single grains of a few microns in diameter and as aggregates up to $20 \mu$. The large spore (SP), $90 \mu$ long, is medium gray with a somewhat higher reflectance than the spore in figure 1, plate 2. $60 \mathrm{X}$ oil immersion objective. Magnification: 600X.

3. Several quartz grains $(Q)$ in different positions of extinction. Most of the grains are single crystals; twinning, where present, is irregular. 12.5X oil immersion objective. Magnification: $120 \mathrm{X}$.

4. Polished surface showing stratified black coal (Sample no. 2), brown transitional layer (fig. 5), and the limestone that contains quartz grains, shell fragments, and a few thin carbonaceous partings near the coaly layer. Actual size.

5. Transitional layer between the coal and the limestone. The angular grains are dolomite and some calcite (X-ray analysis, thin section). Coal occurs only in the interstices. 25X oil immersion objective. Magnification: 250X.

6. Limestone adjacent to coal Sample no. 2. Microstylolites interrupt a thin carbonaceous parting. 25X oil immersion objective. Magnification: 250X. 


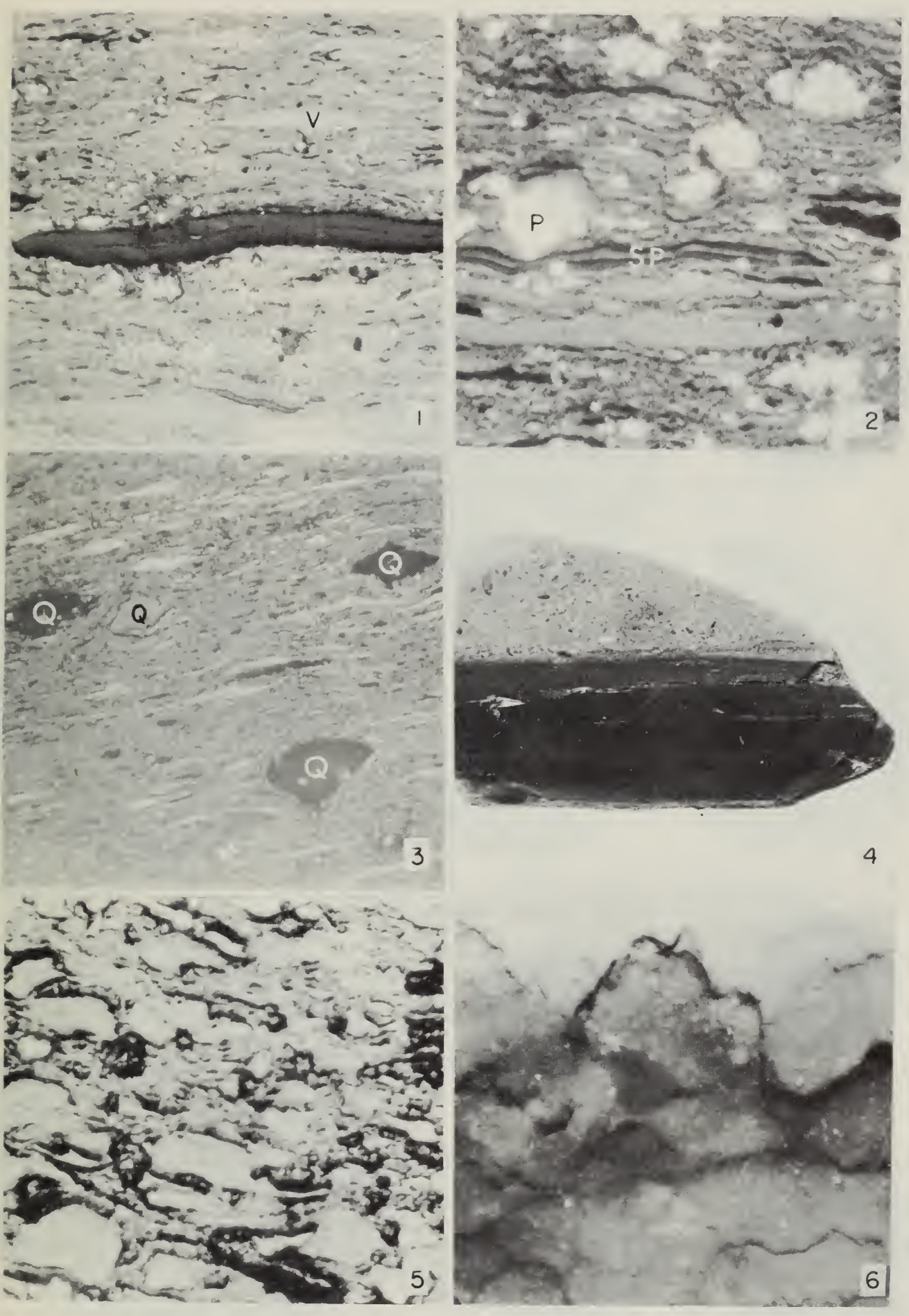




\section{PLATE 3}

\section{All figures 500X unless designated differently}

Figure

1. Punctatisporites solidus Hacquebard, 1957; negative 7964; maceration 1510 , slide 6 , coordinates $130.5 \times 40.1$; size, 49.4 by $47.8 \mu$; p. 9 .

2. Punctatisporites glaber (Naumova) Playford, 1962; negative 7972; maceration 1510 , slide 5, coordinates $144.2 \times 52.0$; size, 61.8 by $60.5 \mu$; p. 9 .

3. Punctatisporites cf. irrasus Hacquebard, 1957; negative 7973; maceration 1510 , slide 5 , coordinates $137.4 \times 38.0$; size, 61.1 by $53.6 \mu$; p. 9 .

4. Punctatisporites aerarius Butterworth and Williams, 1958; negative 7952; maceration $1548, \overline{\text { slide } 7}$, coordinates $126.5 \times 39.1$; size, 87.4 by $67.3 \mu$; p. 9 .

5. Punctatisporites sp.; negative 7951; maceration 1548, slide 1, coordinates $128.7 \times 50.2$; size, 101.1 by $91.7 \mu$; p. 9 .

6. Calamospora atava (Naumova) McGregor, 1964; negative 7967; maceration 1510 , slide 15 , coordinates $132.9 \times 47.3$; size, 59.2 by $51.7 \mu$; p. 10 .

7. Retusotriletes cf. simplex Naumova, 1953; negative 7960; maceration 1510 , slide 10 , coordinates $128.6 \times 47.0$; size, 65.3 by $62.4 \mu$; p. 10 .

8. Retusotriletes obscurus Peppers sp. nov.; holotype; negative 8008; maceration 1510 , slide 4 , coordinates $141.0 \times 42.3$; size, 102.1 by $94.3 \mu$; p. 10 .

9. Retusotriletes obscurus Peppers sp. nov.; paratype; negative 8295; maceration 1510 , slide 7 , coordinates $127.6 \times 52.5$; size, 126.8 by $120.3 \mu$; p. 10 .

10. Retusotriletes striatus Peppers sp. nov.; holotype; negative 8002; maceration 1510 , slide 11 , coordinates $141.2 \times 34.0$; size, 55.3 by $51.0 \mu$; p. 11 .

11. Retusotriletes striatus Peppers sp. nov.; paratype; negative 7977; maceration 1510, slide 12 , coordinates $122.8 \times 33.3$; size, 54.9 by $43.9 \mu$; p. 11 .

12. Retusotriletes striatus Peppers sp. nov.; paratype; negative 8263; maceration 1510 , slide 16 , coordinates $133.3 \times 47.5$; size, 60.8 by $45.5 \mu$; p. 11 .

13. Retusotriletes striatus Peppers sp. nov.; paratype; negative 8282; portion of same spore illustrated in figure 11 , oil immersion objective, magnified $1000 \mathrm{X}$; p. 11.

14. Retusotriletes tenerimedium Chibrikova, 1959; negative 8262; maceration 1548, slide 6 , coordinates $130.5 \times 42.0$; size, 44.9 by $42.6 \mu$; p. 11 .

15. Retusotriletes sp.; negative 7982 ; maceration 1510 , slide 17 , coordinates $126.3 \times 37.4$; size, 70.5 by $61.8 \mu$; p. 11 . 

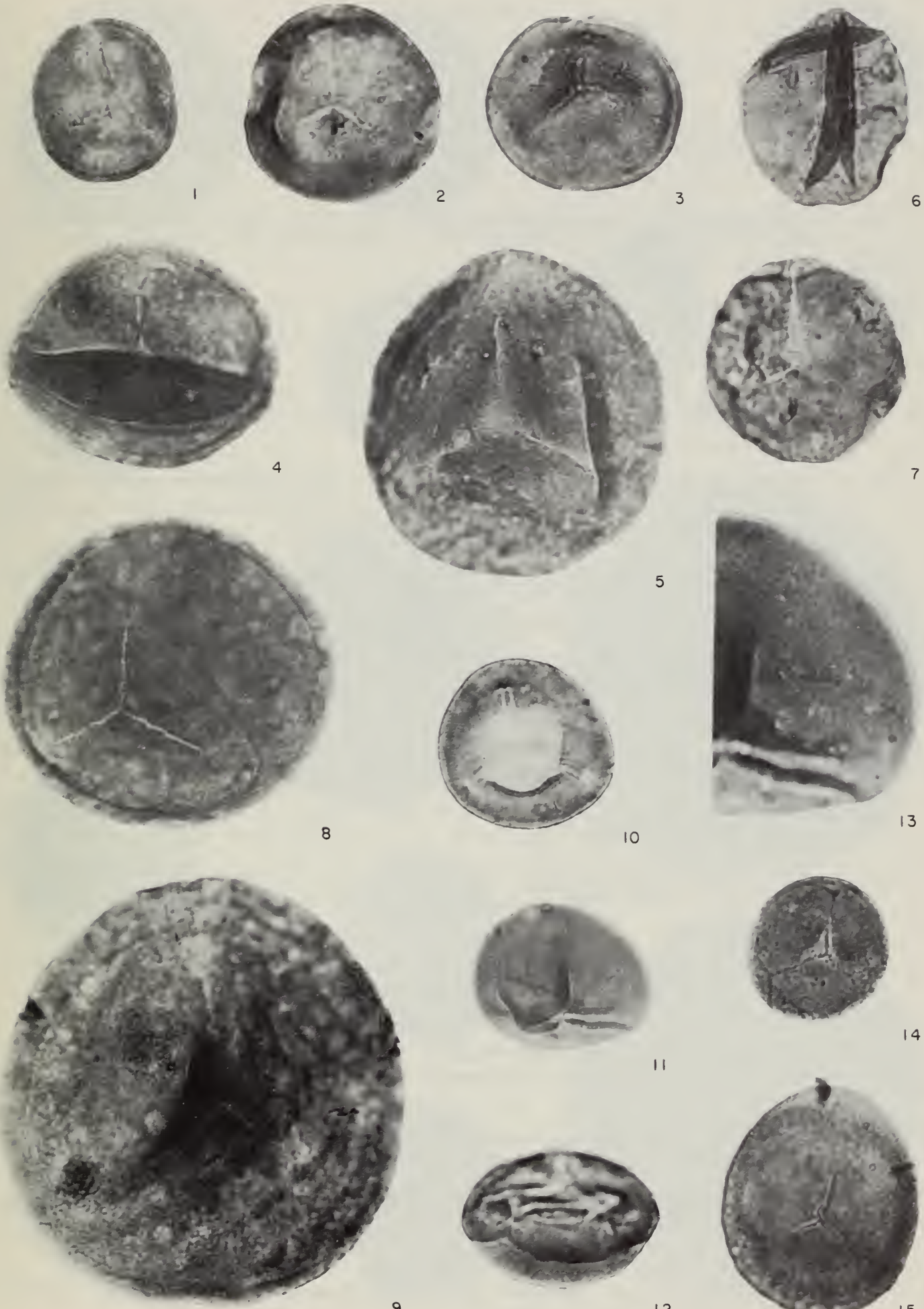

14

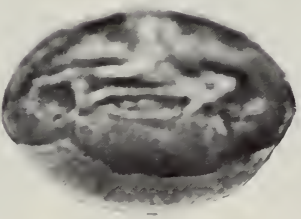

12

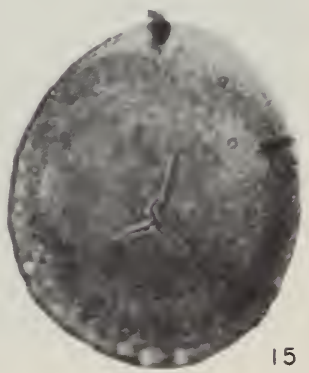


PLATE 4

All figures 500X unless designated differently

Figure

1. Apiculatasporites wapsipiniconensis Peppers sp. nov.; holotype; negative 7953; maceration 1548, slide 3, coordinates $140.0 \times 51.6$; size, 73.8 by $69.9 \mu ;$ p. 12 .

2. Apiculatasporites wapsipiniconensis Peppers sp. nov.; paratype; negative 82.64; maceration 1510, slide 2, coordinates $127.6 \times 45.1$; size, 71.5 by $61.8 \mu ;$ p. 12 .

3. Apiculatasporites davenportensis Peppers sp. nov.; holotype; negative 8283; maceration 1510 , slide 13 , coordinates $135.0 \times 36.0$; size, 31.2 by $28.6 \mu$; oil immersion objective, magnified l000X; p. 12 .

4. Apiculatasporites davenportensis Peppers sp. nov.; paratype; negative 8288; maceration 1510 , slide 19 , coordinates $142.8 \times 57.3$; size, 33.8 by $31.2 \mu ; \mathrm{p} .12$.

5. Apiculatasporites dewittensis Peppers sp. nov.; holotype; negative 8284; maceration 1510 , slide 8 , coordinates $131.8 \times 31.5$; size, 28.6 by $26.0 \mu$; oil immersion objective, magnified l000X; p. 13 .

6. Apiculatasporites dewittensis Peppers sp. nov.; paratype; negative 8286; maceration 1510 , slide 27 , coordinates $140.0 \times 49.5$; size, 23.1 by $19.5 \mu$; oil immersion objective, magnified $1000 \mathrm{X} ; \mathrm{p} .13$.

7. Acanthotriletes uncatus Naumova, 1953; negative 7963; maceration 1510, slide 6 , coordinates $132.6 \times 48.7$; size, 54.6 by $52.7 \mu$, including ornamentation; p. 13 .

8. Acanthotriletes cf. polyganius Naumova, 1953; negative 8290; maceration

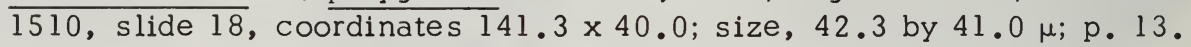

9. Emphanisporites rotatus McGregor, 1961; negative 8266; maceration 1548 , slide 12 , coordinates $142.3 \times 36.0$; size, 44.9 by $45.5 \mu ;$ p. 14 .

10. Lycospora pseudomagnifica Peppers sp. nov.; holotype; negative 8001 ; maceration 1510 , slide 21 , coordinates $138.6 \times 37.5$; size, 69.9 by $58.5 \mu ;$ p. 14 .

11. Lycospora pseudomagnifica Peppers sp. nov.; paratype; negative 8000 ; maceration 1510 , slide 22 , coordinates $128.5 \times 38.3$; size, 63.4 by $52.0 \mu ;$ p. 14 .

12. Lycospora pseudomagnifica Peppers sp. nov.; tetrad; negative 8274; maceration 1510 , slide 23 , coordinates $143.3 \times 49.5$; size, 82.9 by $80.3 \mu$; p. 14 .

13. Lycospora sp.; negative 8267 ; maceration 1510 , slide 4 , coordinates $137.6 \times 50.4$; size, 62.8 by $50.7 \mu$; p. 15 .

14. Spelaeotriletes sp.; negative 8280; maceration 1548, slide 14 , coordinates $122.9 \times 35.5$; over-all size, 122.9 by $118.6 \mu$; intexine, 86.1 by $82.9 \mu$; focus on proximal surface; p. 15.

15. Spelaeotriletes sp.; negative 8281; same specimen as illustrated in figure 14 but focus on distal surface; p. 15 .

16. Spelaeotriletes sp.; negative 8289; maceration 1510 , slide 9, coordinates $129.9 \times 44.2$; over-all size, 91.0 by $86.1 \mu$; intexine, 64.0 by $55.3 \mu$; p. 15 . 

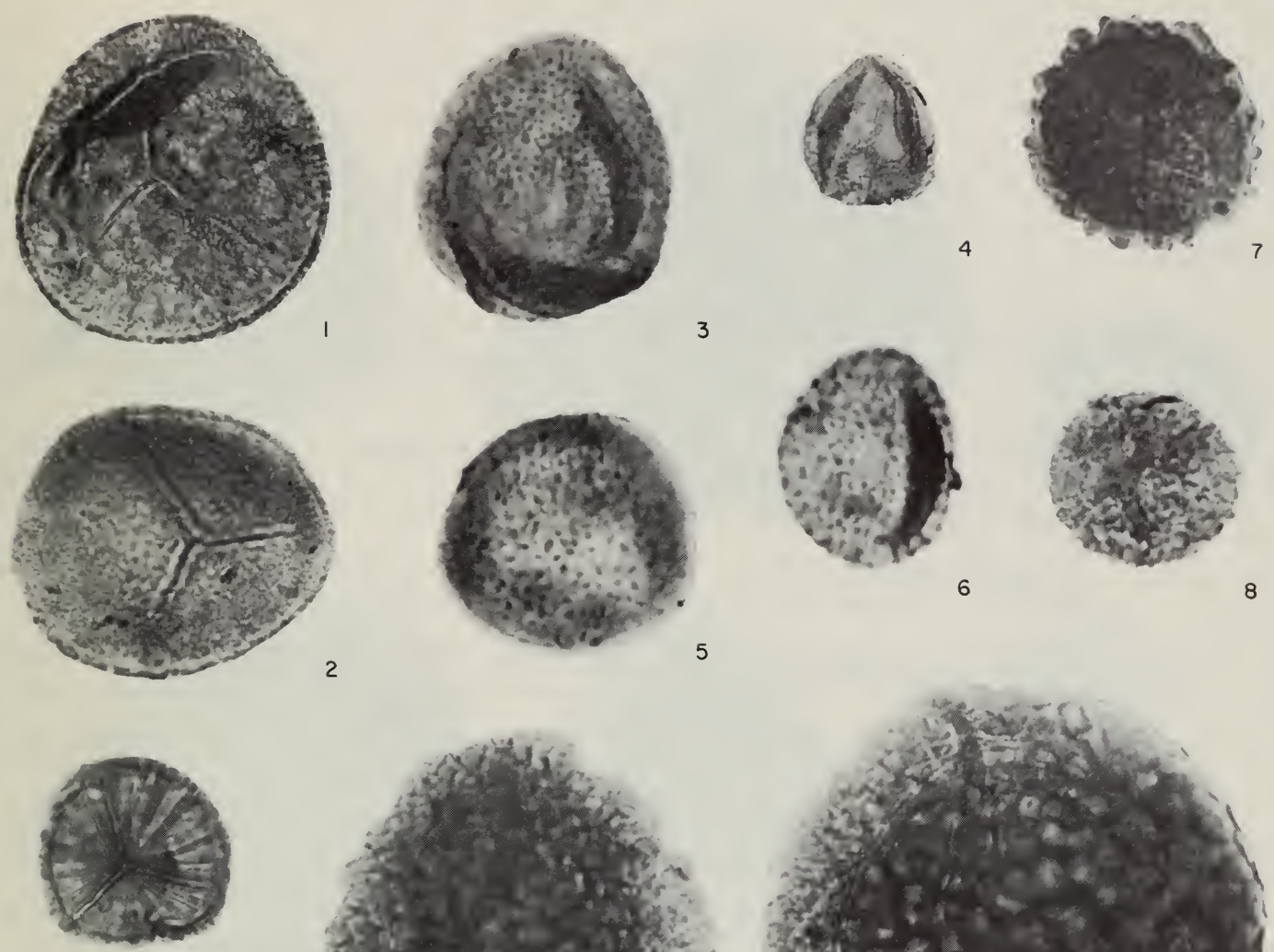

9
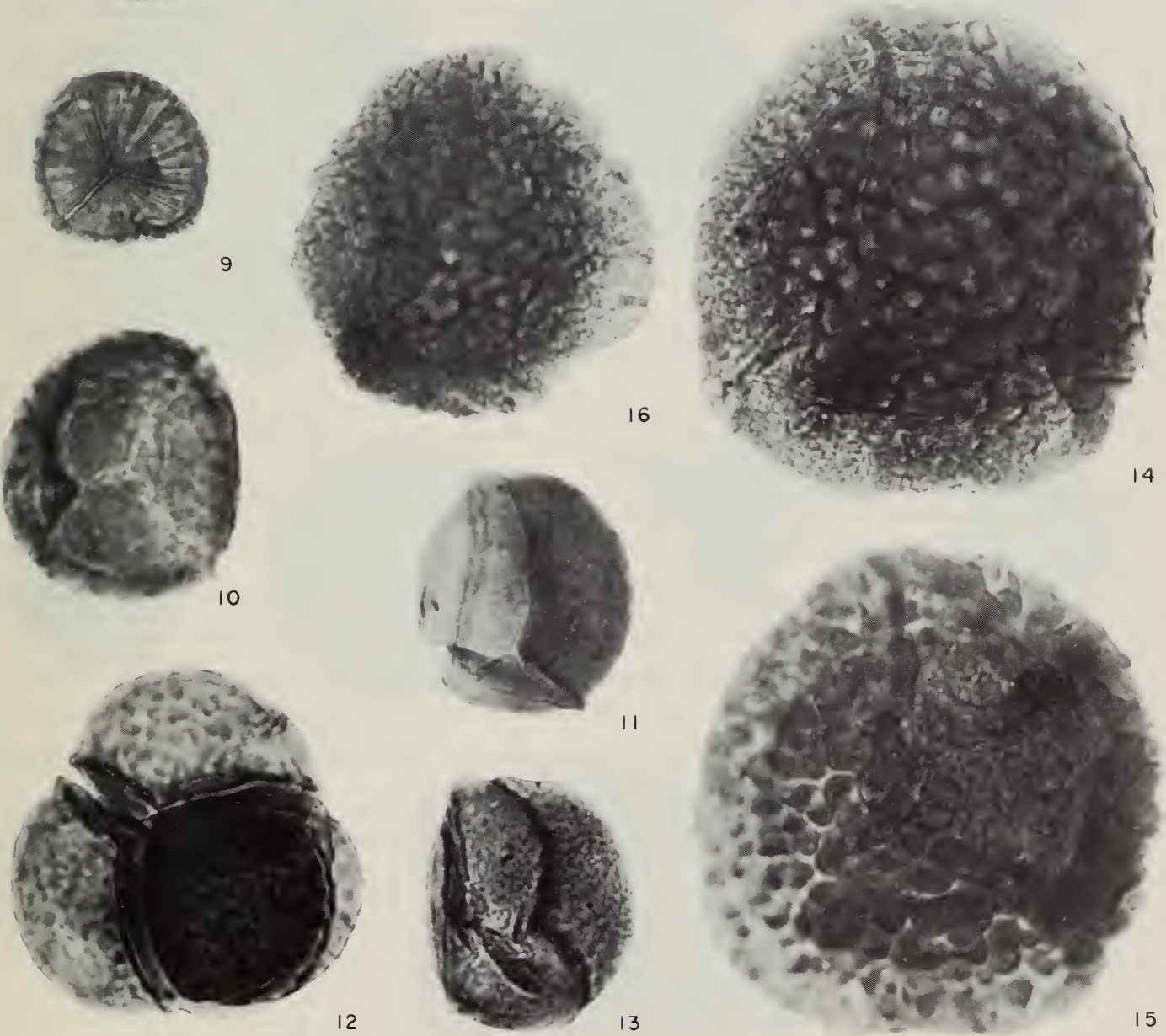
PLATE 5

All figures 500X unless designated differently

Figure

1. Spinozonotriletes cf. tuberculatus Neves and Owens, 1966; negative 8292; maceration 1510 , slide 19 , coordinates $138.1 \times 55.0$; size, 148.2 by $133.9 \mu$; magnified $300 x ; p .16$.

2. Spinozonotriletes cf. naumovii (Kedo) Richardson, 1965; negative 8012; maceration 1510 , slide 8 , coordinates $131.7 \times 45.3$; size, 177 by $169 \mu$; magnified $300 x ; p .16$.

3. Spinozonotriletes (?) sp.; negative 8011 ; maceration 1510 , slide 9, coordinates $127.4 \times 40.0$; size, 195 by $187 \mu$; magnified $300 x ; p .16$.

4. Archaeozonotriletes cf. purus Naumova, 1953; negative 7987; maceration 1510 , slide 24 , coordinates $144.1 \times 32.3$; size, 54.3 by $52 \mu$; .16 .

5. Archaeozonotriletes sp.; negative 8271 ; maceration 1510 , slide 25, coordinates $135.0 \times 39.3$; size, 54.0 by $48.4 \mu$; p. 16 .

6. Rhabdosporites langi (Eisenack) Richardson, 1960; negative 8019 ; maceration 1510, slide 1, coordinates $145.0 \times 41.5$; size, 130.0 by $104.3 \mu$; magnified 300X; p. 17 .

7. Ancyrospora sp.; negative 8294; maceration 1510, slide 26, coordinates $142.5 \times 46.8$; maximum diameter $127 \mu$; magnified 300X; p. 17.

8. Retialetes sp.; negative 7966 ; maceration 1510 , slide 15 , coordinates $140.0 \times 50.7$; size, 52.0 by $43.9 \mu ; \mathrm{p} .17$.

9. Leiosphaeridia sp.; negative 8291; maceration 1510; large spore slide, coordinates $127.9 \times 36.2$; size, 374 by $332 \mu$; magnified $100 \mathrm{X}$; p. 18 .

10. Tasmanites huronensis (Dawson) Winslow, 1962; negative 8018 ; maceration 1510, large spore slide, coordinates $128.9 \times 36.1$; size, 371 by $310 \mu$; magnified 100X; p. 18 .

11. Tasmanites huronensis (Dawson) Winslow, 1962; negative 8285; portion of spore illustrated in figure 10; magnified 1000X; p. 18.

12. Veryhachium octoaster Staplin, 1961; negative 8272; maceration 1548 , slide 2, coordinates $128.5 \times 42$; maximum dimension $63.4 \mu ; \mathrm{p} .18$

13. Algae (?); negative 7968; maceration 1510; slide 15, coordinates 133.0 x 31.1 ; size, 41.6 by $39.0 \mu ; \mathrm{p} .18$.

14. Algae (?), cluster; negative 7959; maceration 1510, slide 10, coordinates $144.7 \times 46$; length of cluster $73.8 \mu ; \mathrm{p} .18$. 

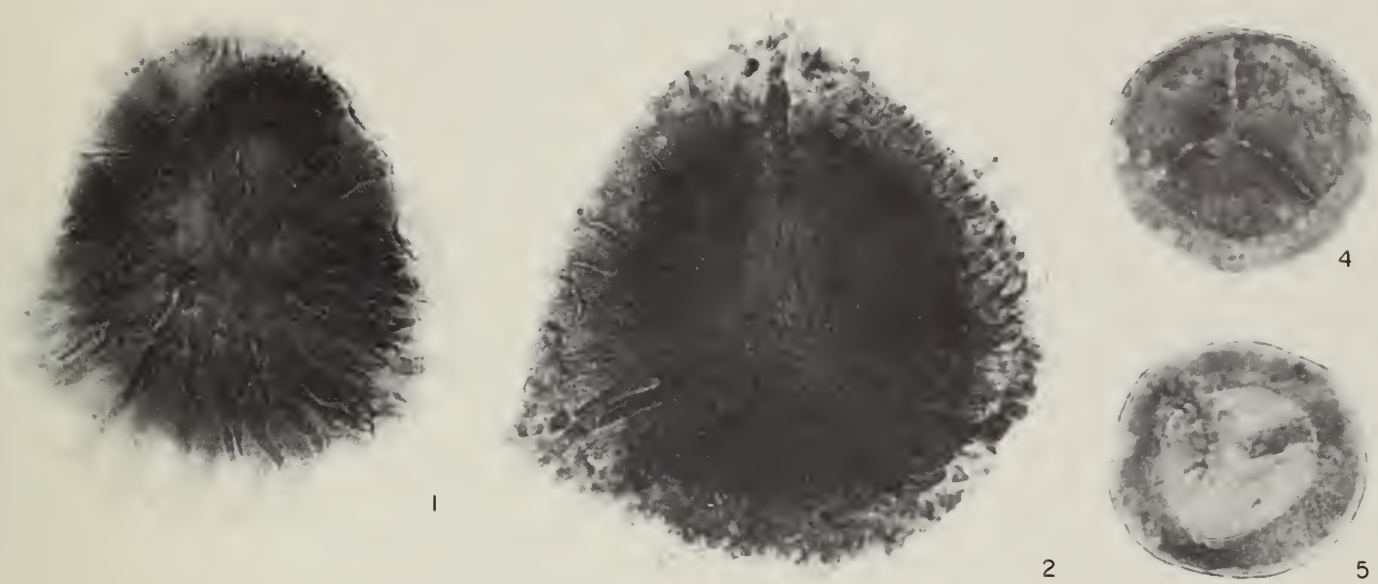

2
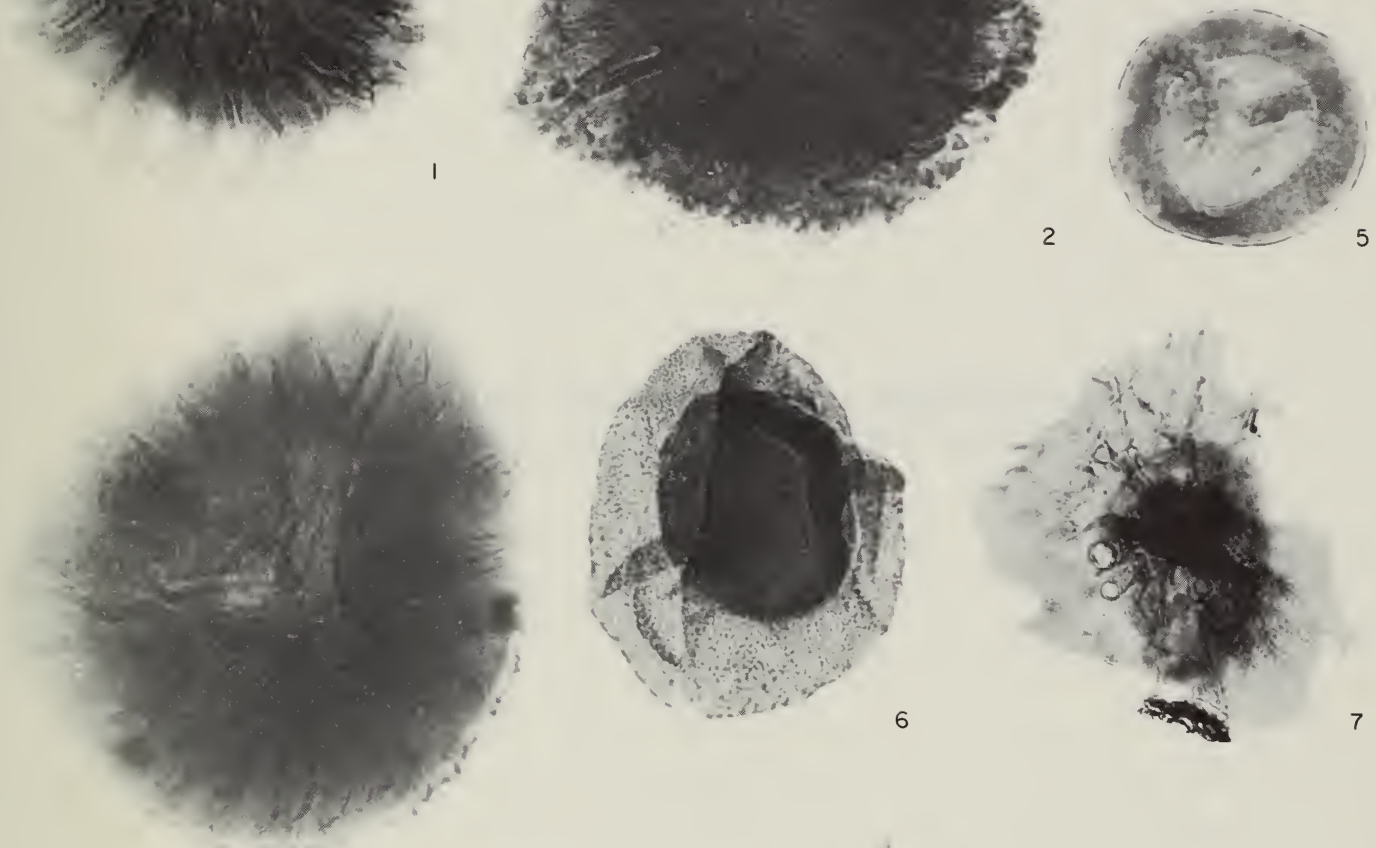

7
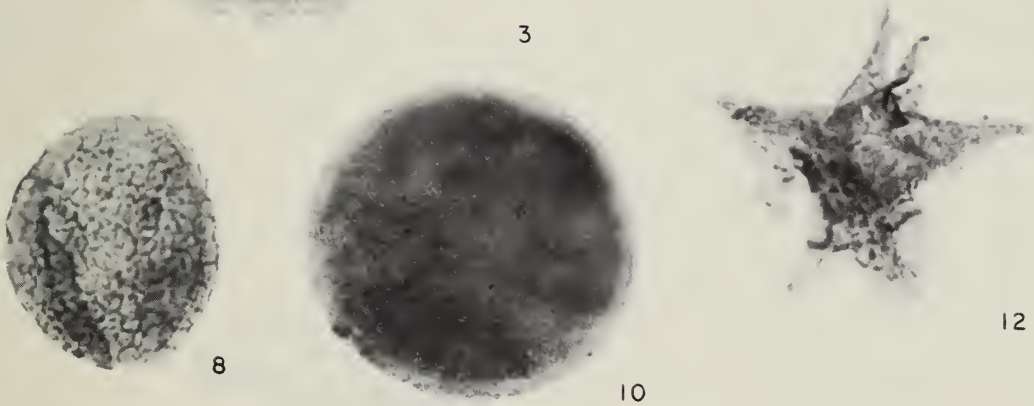

12
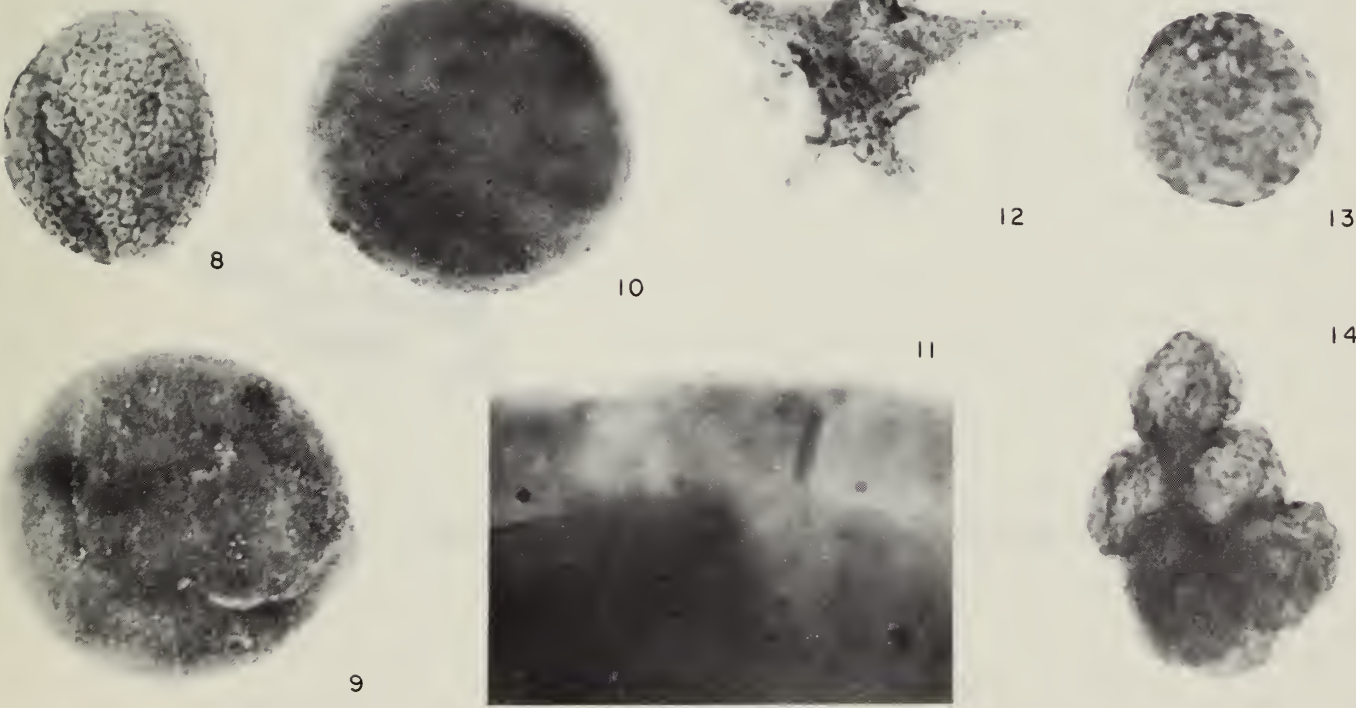
Illinois State Geological Survey Circular 445

36 p., 5 pls., 4 text figs., 3 tables, 2500 cop., 1969

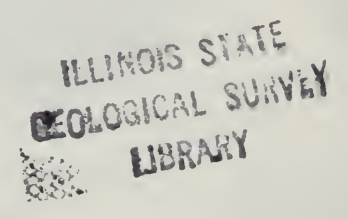

Printed by Authority of State of Illinois, Ch. 127, IRS, Par. 58.25. 

CIRCULAR 445

ILLINOIS STATE GEOLOGICAL SURVEY URBANA 61801 